\title{
Botanical-Drug Interactions: A Scientific Perspective
}

Authors

Affiliation
Manuela de Lima Toccafondo Vieira, Shiew-Mei Huang

Office of Clinical Pharmacology, Center for Drug Evaluation and Research, US Food and Drug Administration, Silver Spring, MD, USA

\section{Key words}

- drug-interactions

- botanical products

- regulatory science

- clinical pharmacology received April 23, 2012

revised July 3,2012

accepted July 6, 2012

Bibliography

Dol http://dx.doi.org/

10.1055/s-0032-1315145

Published online August 3, 2012

Planta Med 2012; 78:

1400-1415 @ Georg Thieme

Verlag KG Stuttgart - New York . ISSN 0032-0943

\section{Correspondence}

Manuela de Lima Toccafondo

Vieira, PhD

Food and Drug Administration

Office of Clinical Pharmacology

10903 New Hampshire Avenue

Silver Spring, MD 20993

United States

mtoccafondo@yahoo.com

\section{Abstract}

$\nabla$

There is a continued predisposition of concurrent use of drugs and botanical products. A general lack of knowledge of the interaction potential together with an under-reporting of botanical use poses a challenge for the health care providers and a safety concern for patients. Botanical-drug interactions increase the patient risk, especially with regard to drugs with a narrow therapeutic index (e.g., warfarin, cyclosporine, and digoxin). Examples of case reports and clinical studies evaluating botanical-drug interactions of commonly used botanicals in the US are presented. The potential pharmacokinetic and pharmacodynamic bases of such interactions are discussed, as well as the challenges associated with the interpretation of the available data and prediction of botanical-drug interactions. Recent FDA experiences with botanical products and interactions including labeling implications as a risk management strategy are highlighted.

\section{Abbreviations}

ADME: absorption, distribution, metabolism, and excretion

\section{Introduction}

$\nabla$

The use of botanicals as dietary supplements has increased significantly over the past decades. The botanical product sales in the US have increased steadily over the years, by $8 \%$ in 2007 over the preceding year, then increasing by $7 \%$ in 2008 and $14 \%$ in 2009 [1]. Recent surveys reveal that approximately $20 \%$ of Americans use botanicals and $20-30 \%$ indicated concurrent use of botanicals with conventional drugs [2,3]. In addition, there is an underreporting of such use to health
AhR: $\quad$ aryl hydrocarbon receptor

AUC: area under the plasma concentrationtime curve

BCRP: breast-cancer resistant protein

DHB: $\quad$ 6',7'-dihydroxybergamottin

CAR: constitutive androstane receptor

$C_{\text {max }}$ : maximum plasma concentration

$\mathrm{C}_{\min }$ : trough plasma concentration

CL/F: apparent oral clearance

CYP: $\quad$ cytochrome P450

FDA: $\quad$ Food and Drug Administration

GFJ: $\quad$ grapefruit juice

$\mathrm{K}_{\mathrm{i}}$ : inhibition constant

MRP: multidrug resistance associated protein

P-gp: $\quad$ P-glycoprotein

PXR: $\quad$ pregnane $X$ receptor

PBPK: $\quad$ physiologically-based pharmacokinetic

OATP: $\quad$ organic anion-transporting polypeptide

SJW: $\quad$ St. John's wort

SULT: $\quad$ sulfotransferase

UGT: UDP-glucuronosyl transferase

Supporting information available online at http://www.thieme-connect.de/ejournals/toc/ plantamedica

care practitioners [4]. As more consumers use botanicals to promote health or to manage various common chronic diseases, for which they often take prescribed drugs concomitantly, the likelihood of potential pharmacokinetic and/or pharmacodynamic botanical-drug interactions increase.

Although the efficacy of some botanicals has been documented [5], there is a concern regarding the perceived safety of these products [6], particularly with respect to knowledge on botanicaldrug interaction potential and its clinical signifi- 
cance [7]. Indeed, clinically significant botanical-drug interactions have been reported. St. John's wort (Hypericum perforatum L.), a popular botanical used in the management of mild or moderate depression, has been shown to adversely alter the pharmacokinetics of several prescribed drugs (e.g., cyclosporine [8] and irinotecan [9]) resulting in therapeutic failure. A recent review of published clinical evidence identified 34 prescription drugs with a potential for interaction with botanical products. Most of the drugs are administered in long-term regimens and include antiretroviral agents, immunosuppressants, cardiovascular and oncology drugs with many of them having a narrow therapeutic index [10].

The purpose of this review is to present an overview of common mechanisms of botanical-drug interactions using specific literature examples. The evaluation of botanical-drug interactions using in vitro approaches and clinical trials, as well as the challenges associated with the interpretation of the results are reviewed and discussed. Moreover, this work highlights the regulatory perspectives on botanical products, including the labeling implications for potential interactions.

\section{Mechanisms of Botanical-Drug Interactions}

$\nabla$

As for any drug-drug interactions, both pharmacokinetic (PK) and pharmacodynamic (PD) mechanisms may be implicated in botanical interactions with prescribed or over-the-counter drugs.

\section{Altered pharmacokinetics}

The most commonly documented botanical-drug interactions affect PK by altering drug absorption, distribution, metabolism, and excretion (ADME). Changes in drug absorption may be mediated through modulation of intestinal uptake and efflux transporters, while changes in metabolism/excretion occur through modulation of hepatic/renal uptake and efflux transporters, and/or through inhibition/induction of metabolizing enzymes. Examples of altered drug distribution as a result of protein binding displacement by botanicals have not been reported. Tissue uptake transporters also play a role in drug distribution, thus modulation of these transporters by botanical constituents may affect plasma and tissue exposure. The primary mechanism of reported botanical-drug PK interactions is modulation of metabolizing enzymes and/or transporters in the intestine and liver.

Modulation of metabolizing enzymes: The human cytochrome P450 (CYP) family of enzymes, including CYP1A1/2, CYP2A6, CYP2B6, CYP2C8/9/19, CYP2D6, CYP2E1, and CYP3A4/5 is involved in the oxidative metabolism (phase I) of the majority of drugs used in clinical practice. CYP3A4 is the most abundant CYP in the liver and intestine. While it catalyzes the metabolism of 50-60\% of current marketed drugs [11], CYP2C19 and CYP2D6 are the major metabolizing enzymes for $15 \%$ and $20 \%$ of drugs, respectively [12]. UDP-glucuronosyl transferases (UGTs) include the UGT1 and UGT2 families of enzymes and are responsible for glucoronidation of $35 \%$ of drugs metabolized by phase II enzymes [13].

Inhibition of enzymes can be classified into reversible and irreversible inhibition. While the competitive mechanism of reversible inhibition results in an almost immediate response, mechanism-based inhibition is characterized by a time- and concentration-dependent blockage [14]. The irreversible inhibition can completely inactivate the drug's metabolism and can persist even after the withdrawal of the botanicals since the recovery of en- zyme activity requires de novo enzyme synthesis. Irreversible inhibition of CYPs has been demonstrated in vitro by diallyl sulfone (in garlic), glabridin (in licorice root), methysticin (in Kava) [15, 16], and silybin (in milk thistle) [17].

The grapefruit juice (GFJ) furanocumarins, 6',7'-dihydroxybergamottin (DHB), bergamottin, and paradisins, are capable of inhibiting CYP activity, both reversibly and irreversibly, with in vitro inhibitory constants in the nanomolar to micromolar range [1820]. Mechanism-based inhibition of CYP3A by DHB and bergamottin may explain the clinically observed irreversible loss of intestinal CYP3A protein, without altered CYP3A mRNA levels, after ingestion of GFJ [20,21]. Examples of the variable content of these enzyme modulators in different grapefruit juice products sold in the US is demonstrated in $\bullet$ Fig. 1 A.

GFJ is a unique CYP3A inhibitor since usual dietary consumption of GFJ inhibits only enteric, but not hepatic CYP3A activity. Clinical evidence has shown that concomitant GFJ ingestion increases the systemic exposure of orally administered CYP3A substrates which have low oral bioavailability due to extensive presystemic extraction by enteric CYP3A [22]. Examples of grapefruit-drug interactions are illustrated in $\odot$ Tables $\mathbf{1}$ and $\mathbf{2}$, and their impact on drug labeling is listed in Table $\mathbf{1 S}$.

Inhibition of CYP3A activity is proposed as the mechanism of interaction between cyclosporine and berberine, an isoquinoline alkaloid of goldenseal (Hydrastis canadensis), a popular botanical used as a topical antimicrobial and for digestive disorders. Cyclosporine (CYP3A4/P-gp substrate) blood concentration was increased in healthy volunteers [23] and in renal transplant recipients [24] after coadministration of $0.3 \mathrm{~g}$ (single dose) or $0.2 \mathrm{~g}$ (tid, 3 months), respectively, of a goldenseal product. Evidence of goldenseal's inhibition potential against CYP3A4, CYP2D6, and CYP2E1 has been demonstrated in vitro [25-27]. Inhibitory effect of berberine on CYP3A4 was observed at lower incubation concentrations ( 0.3 and $1 \mu \mathrm{M})$ while an inductive effect was shown at a higher concentration $(10 \mu \mathrm{M})[27,28]$. Further support of CYP modulation by goldenseal was provided in three clinical studies where CYP2D6 and CYP3A4/5 activity was decreased, while CYP1A2 remained unaltered [29-31] ( Tables 1 and 2). Induction defines any mechanism that results in increased concentration of catalytically active protein involved in drug metabolism and/or transport. The most common mechanism of induction is ligand-dependent biding and activation of nuclear receptors that function as gene transcription factors, such as AhR (aromatic hydrocarbon receptor), CAR (constitutive androstane receptor), and PXR (pregnane X receptor) [32,33]. Induction is a regulated process which requires time to reach a higher steadystate protein level. Also, the transcriptional regulation of enzymes is commonly cell-type and tissue- and species-selective $[12,32]$.

Preclinical and clinical data have provided evidence of St. John's wort (Hypericum perforatum, SJW) inductive effect on several CYP isoforms, including CYP3A4, CYP2C19, and CYP2E1. Chronic exposure of human hepatocytes to hyperforin, but not hypericin, increased mRNA and protein expression, and CYP3A4 activity [34]. The increased CYP3A4 expression by SJW is mediated via PXR activation [35-37] and hyperforin, one of the main active constituents of SJW, is the most potent agonist for PXR. In one study, its binding affinity $\mathrm{K}_{\mathrm{i}}$ was detected to be $27 \mathrm{nM}$ [35]. Induction of intestinal and hepatic CYP3A4 by SJW did alter the bioavailability and clearance of concurrent drugs that are mainly, or partly, metabolized by CYP3A4. For example, long-term SJW treatment reduced the area under the concentration-time curve 


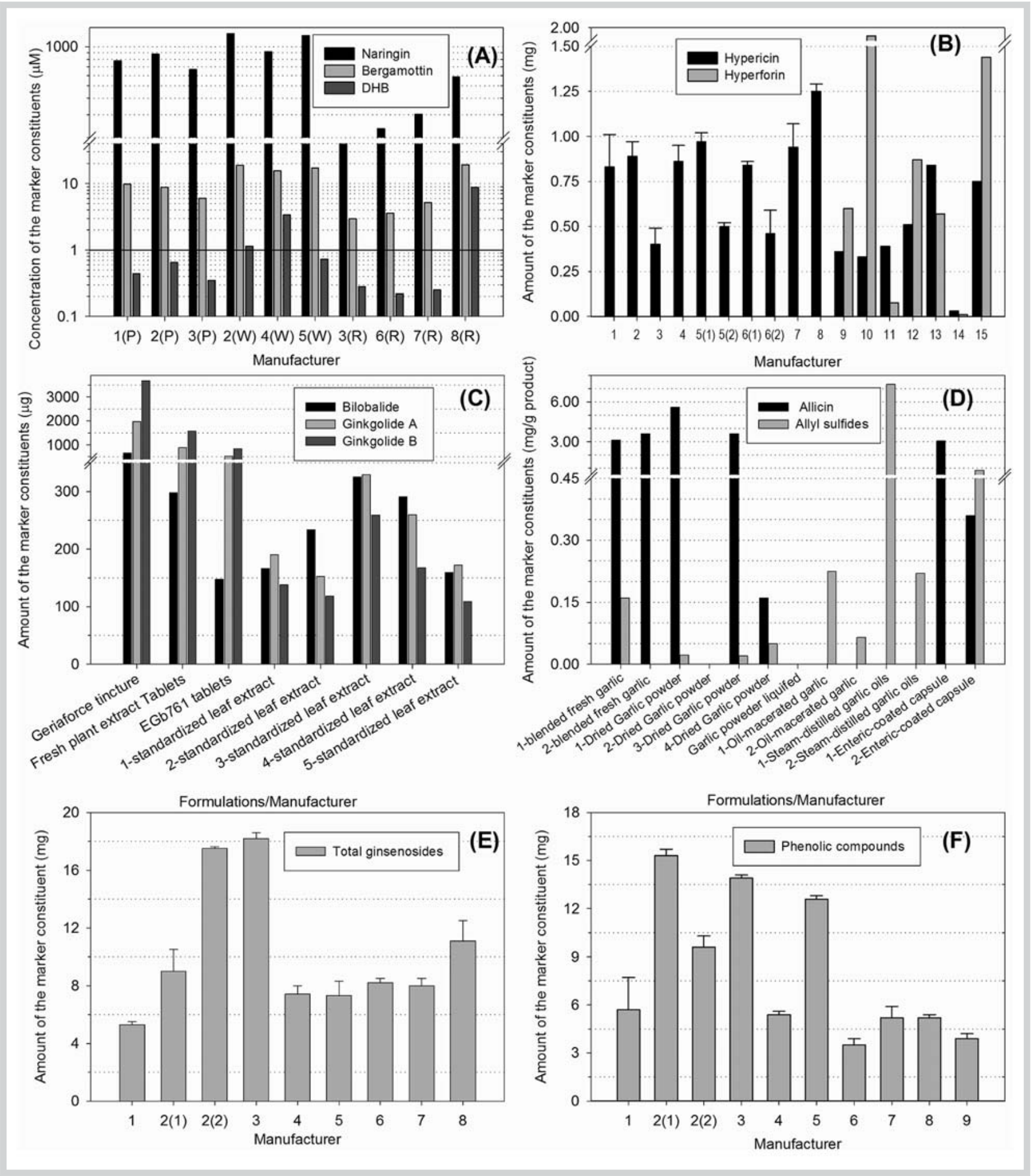

Fig. 1 Comparison of the variability of the marker constituents among different manufacturers (and different lots of the same manufacturer) or formulations of commonly used commercial botanical products in the US grapefruit juice, St. John's wort, Ginkgo biloba, garlic, ginseng, and Echinacea. Bars represent the mean measured amount of the marker compound(s) listed in legends. Error bars (when available) depict the standard deviation of the average of two lots. Numbers in parentheses represent different formulations/preparations from the same manufacturer. A Grapefruit juice. Eight different brands of GFJ using three different varieties pink (P), white (W), and red (R) are demonstrated; from reference [194]. B St. John's wort (Hypericum

perforatum); from references [54, 55]. C Ginkgo biloba. Four different formulations and five commercially available products from different manufacturers were evaluated; from references $[195,196]$. D Garlic (Allium sativa). Six different formulations were evaluated from at least two different manufactures. Bars represent the range of the constituents measured. When a bar is not available, the constituents were not detected (below the limit of detection) in the product; from reference [106]. E Ginseng (Panax ginseng). Marker is reported as total ginsenosides; from reference [55]. $\mathbf{F}$ Echinacea purpurea. Marker is reported as total phenolic compounds, including echinacoside, cattaric acid, chologenic acid, and cichoric acid; from reference [55]. 
Table 1 Effect of botanical product extracts and their active constituents on metabolic enzymes and transporters.

\begin{tabular}{|c|c|c|}
\hline $\begin{array}{l}\text { Botanical (known enzyme/ } \\
\text { transporter modulator) }\end{array}$ & $\begin{array}{l}\text { Enzyme and transporter } \\
\text { affected }^{\mathrm{a}}\end{array}$ & Possible affected drug class (drug example) ${ }^{b}$ \\
\hline Garlic extract (allicin and alliin) & $\begin{array}{l}\text { CYP2D6 }(\leftrightarrow) \text { CYP3A4 }(\leftrightarrow) \\
\text { CYP1A2 }(\leftrightarrow) \text { CYP2C9 }(\leftrightarrow) \\
\text { P-gP }(\uparrow) \\
\text { CYP2E1 }(\downarrow)\end{array}$ & Antiretroviral (saquinavir) $[97,98]$, CYP2E1 probe chlorzoxazone $[45,46]$ \\
\hline $\begin{array}{l}\text { Ginkgo biloba [Flavonoids } \\
\text { (e.g., quercetin, kaempferol) and } \\
\text { terpenoids (ginkgolides A and B, } \\
\text { and bilobalide)] }\end{array}$ & $\begin{array}{l}\text { CYP2D6 }(\leftrightarrow) \text { CYP3A4 }(\leftrightarrow) \\
\text { CYP2C19 }(\uparrow) \\
\text { CYP2C9 }(\text { possible } \downarrow) \\
\text { P-gp }(\downarrow) \\
\text { OATP2B1 }(\downarrow)\end{array}$ & $\begin{array}{l}\text { Antihistamine (fexofenadine) }[79,197] \text {, beta-blocker (talinolol) }[76,77] \text {, proton } \\
\text { pump inhibitor (omeprazole) }[188]\end{array}$ \\
\hline $\begin{array}{l}\text { Ginseng (Ginsenoside Rb1, Rb2, } \\
\text { Rc, Rd, Re, and Rf) }\end{array}$ & 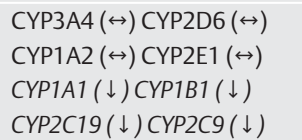 & \\
\hline $\begin{array}{l}\text { Goldenseal (Alkaloids berberine } \\
\text { and hydrastine) }\end{array}$ & $\begin{array}{l}\mathrm{CYP} 3 \mathrm{~A} 4(\downarrow) \mathrm{CYP} 2 \mathrm{D} 6(\downarrow) \\
\mathrm{CYP} 1 \mathrm{~A} 2(\leftrightarrow) \mathrm{CYP} 2 \mathrm{E} 1(\leftrightarrow)\end{array}$ & $\begin{array}{l}\text { Central nervous system agent (midazolam) [31], CYP2D6 probe debrisoquine [29], } \\
\text { immunosuppressant (cyclosporine) [23, 24] }\end{array}$ \\
\hline $\begin{array}{l}\text { Grapefruit juice (Flavonoids narin- } \\
\text { gin/naringenin and quercetin, and } \\
\text { furanocoumarins bergamottin, } \\
\text { 6'7'-dihydroxybergamottin) }\end{array}$ & $\begin{array}{l}\text { Enteric CYP3A4 }(\downarrow) \\
\text { P-gp }(\downarrow) \\
\text { OATP1A2 }(\downarrow) \\
\text { OATP2B1 }(\downarrow)\end{array}$ & $\begin{array}{l}\text { Antihistamines (fexofenadine, terfenadine), anti-infectives (e.g., erythromycin, } \\
\text { halofantrine, praziquantel), antiretrovirals (saquinavir), cardiovascular drugs (e.g., } \\
\text { aliskiren, azelnidipine, celiprolol, felodipine, manidipine, nicardipine, nifedipine, } \\
\text { nimodipine, nisoldipine, talinolol), central nervous system agents (e.g., alfentanil, } \\
\text { buspirone, carbamazepine, diazepam, fluvoxamine, methadone, midazolam, phe- } \\
\text { nytoin, sertraline, triazolam), immunosuppressants (e.g., cyclosporine, tacrolimus), } \\
\text { statins (e.g., atorvastatin, lovastatin, simvastatin), oncology agents (etoposide) } \\
\text { [22] }]^{\ddagger}\end{array}$ \\
\hline $\begin{array}{l}\text { Milk thistle (Flavonolignans } \\
\text { silybin) }\end{array}$ & $\begin{array}{l}\text { CYP2C9 }(\downarrow) \text { CYP3A4 }(\leftrightarrow) \\
\text { CYP1A2 }(\leftrightarrow) \text { CYP2D6 }(\leftrightarrow) \\
\operatorname{CYP2E1~} \leftrightarrow) \text { CYP2C8 }(\downarrow) \\
\operatorname{UGT1A6/9}(\downarrow) \cup G T 1 A 1(\downarrow) \\
U G T 2 B 7 / 15(\downarrow) \\
(\operatorname{OATP} 1 B 1 \leftrightarrow) \\
\text { P-gP }(\downarrow) M R P 1(\downarrow)\end{array}$ & Cardiovascular drugs (e.g., losartan [169] and talinolol [198]) \\
\hline $\begin{array}{l}\text { St. John's wort [Phloroglucinol } \\
\text { hyperforin and flavonoids (e.g., } \\
\text { quercetin)] }\end{array}$ & $\begin{array}{l}\operatorname{CYP1A2}(\uparrow) \operatorname{CYP} 2 \mathrm{E} 1(\uparrow) \\
\operatorname{CYP3A} 4(\uparrow) \operatorname{CYP} 2 \mathrm{C9}(\uparrow) \\
\operatorname{CYP2C19}(\uparrow) \operatorname{P-gP}(\uparrow) \\
\operatorname{UGT1A6}(\downarrow)\end{array}$ & $\begin{array}{l}\text { Antiretrovirals (e.g., indinavir, lamivudine, nevirapine), cardiovascular drugs (e.g., } \\
\text { digoxin, ivabradine, nifedipine, talinolol, verapamil, warfarin), central nervous sys- } \\
\text { tem agents (e.g., amitriptyline, alprazolam, buspirone, methadone, midazolam, } \\
\text { phenytoin, sertraline), hypoglycaemic agents (gliclazide), immunosuppressants } \\
\text { (e.g., cyclosporine, tacrolimus), statins (e.g., atorvastatin, simvastatin), oncology } \\
\text { agents (imatinib, irinotecan), proton pump inhibitors (e.g., cimetidine, omepra- } \\
\text { zole,), respiratory system agents (e.g., fexofenadine, theophylline) [92, 93] }]^{\ddagger}\end{array}$ \\
\hline
\end{tabular}

a The enzymes and/or transporters modulating effect $[(\uparrow)$ increase, $(\downarrow)$ decrease, $(\leftrightarrow)$ no effect] are based on human trials except those in italic, which are based on in vitro data only. ${ }^{b}$ Listed drugs with published clinical drug-botanical interaction based on pharmacokinetic mechanism. ${ }^{*}$ References in brackets refer to comprehensive reviews of botanicaldrug interactions with details of the respective clinical trials

(AUC) and/or maximum plasma concentration $\left(\mathrm{C}_{\max }\right)$ of nevirapine [38], ivabradine [39], quazepam [40], and verapamil [41]. SJW (standardized extract, $0.825 \mathrm{mg}$ hypericin, and $12.5 \mathrm{mg}$ hyperforin, 3 tablets/day, 14 days) increased the oral clearance of both enantiomers of warfarin, 29\% for S-warfarin (CYP2C9 substrate) and 23\% for R-warfarin (CYP3A4/CYP1A2 substrate), resulting in a significant reduction of the anticoagulant effect of rac-warfarin [42].

A dose-dependent effect of SJW against CYP2C19 and CYP2E1 was observed in human hepatocytes; inhibition at a low incubation concentration $(8 \mu \mathrm{g} / \mathrm{mL})$ and induction at a higher concentration $(800 \mu \mathrm{g} / \mathrm{mL})$ [43]. Also, CYP1A2 protein expression raised $2 \%, 30 \%$, and $90 \%$ by increasing concentrations of SJW extracts (100-, 10-, and 1- fold dilution of $9.4 \mathrm{mM}$ of hypericin and $10 \mathrm{mM}$ hyperforin) in human intestinal cells (LS180) [44]. In humans, the inductive effect of SJW ( $900 \mathrm{mg} /$ day, 14 days) on CYP2E1 and CYP2C19 was demonstrated by the increase in the serum metabolic ratio of clorzoxazone $[45,46]$ and in the urinary excretion of mephenytoin metabolite [47], respectively. Additionally, SJW induced both CYP3A4-catalyzed sulfoxidation and
CYP2C19-dependent hydroxylation of omeprazole resulting in a CYP2C19 genotype-dependent decrease in omeprazole AUC and $C_{\max }$ [48] ( Table 2). SJW constituents also likely mediated the induction of CYP2C9 metabolism (and/or CYP2C19) of gliclazide ( $47 \%$ increase in the oral clearance) leading to a reduction in the drug's AUC and half-life [49]. On the other hand, short-term and long-term SJW coadministration failed to alter the PK of tolbutamide, a CYP2C9 substrate, in two PK studies [50,51]. Induction of CYP1A2 (20\% increase in the metabolic ratio of caffeine) was observed only in the female population using SJW (300 mg tid, 14 days) [52] in one study whereas no effect was observed in three other trials $[45,46,50]$. Interestingly, theophylline plasma concentration was decreased in a female patient after SJW administration [53]. The inconsistency in the clinical observations may be explained by the variability on the content of SJW components found among products $[54,55]$ including the constituent of the botanical that is responsible for enzyme induction, hyperforin (○ Fig. 1B).

Additionally, botanicals such as SJW may exhibit a biphasic effect on CYP enzymes: an initial inhibitory effect when given $24 \mathrm{hr}$ pri- 
Table 2 Selected examples of clinical botanical-drug interactions involving drugs that are CYP, P-gp, and OATP substrates.

\begin{tabular}{|c|c|c|c|}
\hline Botanical product (study design) & $\begin{array}{l}\text { Prescribed/probe } \\
\text { drug (dosage) }\end{array}$ & Clinical interaction outcome (possible mechanism) & $\begin{array}{l}\text { Refer- } \\
\text { ence }\end{array}$ \\
\hline $\begin{array}{l}\text { Echinacea purpurea ( } 500 \text { mg extract, tid, } 28 \text { days, } n=8 \\
\text { male and } 5 \text { female healthy volunteers) }\end{array}$ & $\begin{array}{l}\text { Midazolam } \\
\text { (8 mg SD) }\end{array}$ & $27 \% \downarrow$ in $\mathrm{AUC}$ and $37 \% \uparrow$ in $\mathrm{CL} / \mathrm{F}$ (induction of CYP3A) & [199] \\
\hline $\begin{array}{l}\text { Ginkgo biloba (standardized extract with } 23 \% \text { flavonol gly- } \\
\text { cosides and } 7 \% \text { terpene lactones, } 140 \mathrm{mg} \text { bid, } 12 \text { days, } n=6 \\
\text { CYP2C19 homozygous EM, } n=5 \text { heterozygous EM, } n=7 \text { PM } \\
\text { healthy Chinese males) }\end{array}$ & $\begin{array}{l}\text { Omeprazole } \\
\text { (40 mg SD) }\end{array}$ & $\begin{array}{l}\text { In PM, } 25 \% \downarrow \text { in AUC metabolic ratio. In homozygous and } \\
\text { heterozygous EM, } 58 \% \downarrow \text { and } 47 \% \downarrow \text { in AUC metabolic ratio, } \\
\text { respectively (genotype-dependent induction of CYP2C19) }\end{array}$ & [188] \\
\hline $\begin{array}{l}\text { Ginkgo biloba (standardized extract, } 120 \mathrm{mg} \text { tid, } 14 \text { days, } \\
\mathrm{n}=12 \text { male healthy volunteers) }\end{array}$ & $\begin{array}{l}\text { Talinolol } \\
\text { (100 mg SD) }\end{array}$ & $21 \% \uparrow$ in AUC and $33 \% \uparrow$ in $C_{\max }$ (inhibition of $\mathrm{Pg}-\mathrm{p}$ ) & [76] \\
\hline $\begin{array}{l}\text { Ginkgo biloba (standardized extract, } 120 \mathrm{mg} \text { tid, } 24 \text { days, } \\
\mathrm{n}=10 \text { male Chinese healthy volunteers) }\end{array}$ & $\begin{array}{l}\text { Talinolol }(100 \mathrm{mg} \text {, } \\
\text { days 9-23) }\end{array}$ & $26 \% \uparrow$ in AUC and $36 \% \uparrow$ in $C_{\max }$ (inhibition of $\mathrm{Pg}-\mathrm{p}$ ) & [77] \\
\hline $\begin{array}{l}\text { Goldenseal (as berberine } 0.2 \mathrm{~g} \text { tid, } 3 \text { months, } \mathrm{n}=52 \text { renal- } \\
\text { transplant recipients) }\end{array}$ & $\begin{array}{l}\text { Cyclosporine } \\
\text { ( } 3 \mathrm{mg} / \mathrm{kg} \text { bid, } 3 \\
\text { months) }\end{array}$ & $29 \% \uparrow$ in $C_{\min }$ (inhibition of CYP3A) & [24] \\
\hline $\begin{array}{l}\text { Goldenseal ( } 900 \mathrm{mg} \text { root extract, tid, } 28 \text { days, } n=6 \text { male } \\
\text { and } n=6 \text { female healthy volunteers) }\end{array}$ & $\begin{array}{l}\text { Midazolam } \\
\text { (8 mg SD) }\end{array}$ & $40 \% \downarrow$ in serum metabolic ratio (inhibition of CYP3A) & [29] \\
\hline $\begin{array}{l}\text { Goldenseal ( } 1227 \mathrm{mg} \text { root extract with } 77 \mathrm{mg} \text { of berberine, } \\
\text { and } 132 \mathrm{mg} \text { of hydrastine, tid, } 14 \text { days, } \mathrm{n}=8 \mathrm{male} \text { and } \mathrm{n}=8 \\
\text { female healthy volunteers) }\end{array}$ & $\begin{array}{l}\text { Midazolam } \\
(8 \mathrm{mg} \text { SD) }\end{array}$ & $\begin{array}{l}62 \% \uparrow \text { in AUC, } 41 \% \uparrow \text { in } \mathrm{C}_{\max } \text {, and } 36 \% \downarrow \text { in } \mathrm{CL} / \mathrm{F} \\
\text { (inhibition of CYP3A) }\end{array}$ & [31] \\
\hline $\begin{array}{l}\text { Goldenseal ( } 900 \mathrm{mg} \text { root extract, tid, } 28 \text { days, } \mathrm{n}=6 \text { male } \\
\text { and } \mathrm{n}=6 \text { female healthy volunteers) }\end{array}$ & $\begin{array}{l}\text { Debrisoquine } \\
\text { ( } 5 \mathrm{mg} \mathrm{SD})\end{array}$ & $40 \% \downarrow$ in urinary recovery ratio (inhibition of CYP2D6) & [29] \\
\hline $\begin{array}{l}\text { Grapefruit juice } \#\left(200 \mathrm{ml} \text { double-strength }{ }^{* \#} \text {, tid for } 2 \text { days, }\right. \\
\text { day } 3: 200 \mathrm{ml} \text { with simvastatin single dose and at } 30 \text { and } \\
90 \text { min postdose, } n=10 \text { healthy volunteers }) \text { or } \S(8 \text { oz. } \\
(237 \mathrm{~mL}) \text { single-strength }{ }^{*} \text { morning for } 3 \text { days, simvastatin } \\
\text { dosed in the evening day } 3, n=16 \text { healthy volunteers })\end{array}$ & $\begin{array}{l}\text { Simvastatin } \\
\left({ }^{\#} 60 \text { or }{ }^{\S} 20 \mathrm{mg} \mathrm{SD}\right)\end{array}$ & $\begin{array}{l}\# 1500 \% \uparrow \text { or } \S 90 \% \uparrow \text { in } A U C \text { of simvastatin, and }{ }^{\#} 580 \% \uparrow \text { or } \\
\S 30 \% \uparrow \text { in AUC of simvastatin acid; } \# 840 \% \uparrow \text { or }{ }^{\S} 80 \% \uparrow \text { in } \\
C_{\max } \text { of simvastatin, and } \# 550 \% \uparrow \text { or }{ }^{\S} 30 \% \uparrow \text { in } C_{\max } \text { of } \\
\text { simvastatin acid (inhibition of enteric CYP3A4) }\end{array}$ & $\begin{array}{l}{[200]^{\#}} \\
{[201]^{\# \S}}\end{array}$ \\
\hline $\begin{array}{l}\text { Grapefruit juice ( } 200 \mathrm{ml} \text { normal strength, tid for } 5 \text { days, day } \\
3: 200 \mathrm{ml} \text { with aliskiren dose in the morning and at } 4 \text { and } 12 \\
\text { hours postdose, } n=5 \text { female and } n=6 \text { male healthy volun- } \\
\text { teers) }\end{array}$ & $\begin{array}{l}\text { Aliskiren } \\
\text { (150 mg SD) }\end{array}$ & $81 \% \downarrow$ in $C_{\max }, 61 \% \downarrow$ in AUC (inhibition of OATP2B 1 ) & {$[202]$} \\
\hline $\begin{array}{l}\text { Kava ( } 1000 \mathrm{mg} \text { root extract, bid, } 28 \text { days, } \mathrm{n}=6 \text { male and } \\
\mathrm{n}=6 \text { female healthy volunteers) }\end{array}$ & $\begin{array}{l}\text { Chorzoxazone } \\
\text { ( } 250 \mathrm{mg} \text { SD) }\end{array}$ & $40 \% \downarrow$ in serum metabolic ratio (inhibition of CYP2E1) & [29] \\
\hline $\begin{array}{l}\text { St. John's wort ( } 600 \mathrm{mg} \text { extract, } \mathrm{qd}, 14 \text { days, } \mathrm{n}=11 \text { renal } \\
\text { transplant patients) }\end{array}$ & $\begin{array}{l}\text { Cyclosporine } \\
\text { (median } 2.8 \mathrm{mg} / \\
\mathrm{kg} / \text { day) }\end{array}$ & $\begin{array}{l}46 \% \downarrow \text { in AUC, } 42 \downarrow \text { in Cmax } 41 \% \downarrow \text { in } \mathrm{C}_{\text {min }} \text {; Cyclosporine } \\
\text { dose adjustment was required to ensure concentrations are } \\
\text { within the therapeutic range (induction of CYP3A and P-gP) }\end{array}$ & [87] \\
\hline $\begin{array}{l}\text { St. John's wort ( } 300 \mathrm{mg} \text { extract, tid, } 14 \text { days, } \mathrm{n}=6 \\
\text { CYP2C19*1 } 1 /^{*} 1, \mathrm{n}=\left.4 \mathrm{CYP} 2 \mathrm{C} 19^{*} 2\right|^{*} 2 \text { and } \mathrm{n}=\left.2 \mathrm{CYP} * 2\right|^{*} 3 \\
\text { healthy males) }\end{array}$ & $\begin{array}{l}\text { Omeprazole } \\
\text { ( } 20 \mathrm{mg} \text { qd, } 14 \text { days) }\end{array}$ & $\begin{array}{l}44 \% \downarrow \text { and } 38 \% \downarrow \text { in AUC of omeprazole, } 37 \% \uparrow \text { and } 0 \% \text { in } \\
\text { AUC of } 5 \text {-OH-omeprazole, } 136 \% \uparrow \text { and } 159 \% \uparrow \text { in AUC of } \\
\text { omeprazole sulfone in subjects with CYP2C19 wild-type and } \\
\text { variant, respectively. (induction of CYP3A and CYP2C19) }\end{array}$ & [48] \\
\hline
\end{tabular}

Abbreviations: $C_{\max }$, maximum plasma concentration; $C_{\min }$, trough plasma concentration; AUC, area under the plasma concentration-time curve; $S D$, single dose administration; EM, extensive metabolizers; PM, poor metabolizers; CL/F, apparent oral clearance; $\uparrow$ increase $\downarrow$ decrease. ${ }^{* \#}$ Double-strength: one can of GFJ frozen concentrate diluted with one can of water. ${ }^{*}$ Single-strength: one can of GFJ frozen concentrate diluted with 3 cans of water

or to testing with induction after chronic exposure [34]. Using CYP recombinant systems, hyperforin behaved as a competitive inhibitor of CYP3A4 $\left(\mathrm{K}_{\mathrm{i}}=0.48 \mu \mathrm{M}\right)$ and CYP2C9 $\left(\mathrm{K}_{\mathrm{i}}=1.8 \mu \mathrm{M}\right)$ and a noncompetitive inhibitor of CYP2D6 $\left(\mathrm{K}_{\mathrm{i}}=1.5 \mu \mathrm{M}\right)$. I3,II8-biapigenin, a flavonoid component of SJW, was also shown to be a competitive inhibitor of CYP3A4 $\left(\mathrm{K}_{\mathrm{i}}=0.038 \mu \mathrm{M}\right)$, CYP2C9 $\left(K_{i}=0.32 \mu \mathrm{M}\right)$, and CYP1A2 $\left(K_{i}=0.95 \mu \mathrm{M}\right)$ [56]. The acute inhibitory potential of SJW constituents was confirmed in another in vitro study [34,57]. In humans, single-dose exposure of SJW caused inhibition of voriconazole (CYP2C19/CYP2C9/CYP3A4 substrate) metabolism, while long exposure led to induction [58]. Details of this and other examples of SJW-mediated interactions and drugs that are likely to interact with SJW are discussed throughout this work and listed in $\odot$ Table 1 and Table $1 S$.

Interactions resulting from Ginkgo biloba modulation of CYP2C9 function remain controversial. Ginkgo extract competitively inhibited CYP2C9 $\left(K_{\mathrm{i}}=14.8 \mu \mathrm{g} / \mathrm{mL}\right)$ in human liver microsomes [59]; but in clinical trials, coadministration of the standardized ginkgo leaf extract (EGb-761), given either as $80 \mathrm{mg} /$ day or
$240 \mathrm{mg} /$ day for 3 or 7 days, had no effect on the PK of the CYP2C9 substrates tolbutamine, diclofenac [59], warfarin [60], and ticlopidine [61] in healthy subjects. However, using a higher dose ( $360 \mathrm{mg} /$ day) for a longer period (28 days) than those used in the previous studies, the AUC of tolbutamide was decreased by $16 \%$ in healthy volunteers, possibly indicating CYP2C9 induction [62]. Again, the disagreement among studies may also be due to the variable content of the active constituents that may be found

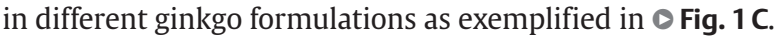
Compared to CYP enzymes, evidence of the modulation of phase II enzymes by botanicals is limited. Ginkgo extract increased glutathione S-transferase (GST) expression and activity levels in HepG2 and Hep1c1c7 cells lines [63] and in rodents after 1 week of exposure [64]. Ginkgo extract and its main flavonoids, quercetin and kaempferol, may also modulate UGT enzymes as demonstrated by the inhibition of the glucuronidation of mycophenolic acid in human microsomes; while ginkgo terpenoids, ginkgolides $A$ and B, and bilobalide, showed no effect [65]. 
Silybin, an active flavonolignan of milk thistle (Silybum marianum), was shown to be a potent inhibitor of UGT1A1 ( IC $_{50}$ of $1.4 \mu \mathrm{M})$ and other UGTs with less potency $\left(\mathrm{IC}_{50}\right.$ range $=28$ $75 \mu \mathrm{M})$ [17]. Silybin also inhibited CYP3A4 activity in vitro $\left(\mathrm{K}_{\mathrm{i}}\right.$ range $=5-160 \mu \mathrm{M}$ ) [17]. However, the modulation of these enzymes has not been observed in vivo. Administration of milk thistle extract (standardized $80 \%$ of silymarin, $200 \mathrm{mg}$ tid, for 4 or 12 days) did not affect the PK of irinotecan (CYP3A4/UGT1A1 substrate) in six cancer patients. This appears to be consistent with the low levels of the components with enzyme modulation activity achieved in vivo. The range of the maximum plasma concentration of silybin was 0.0249 to $0.257 \mu \mathrm{M}$ [66], which is below the in vitro inhibition constants of UGT1A1 and CYP3A4.

Modulation of transporters: Recently, many human drug transporters have been identified (Fig. 1S) and P-glycoprotein (P-gp), expressed by the MDR1 gene, is the best characterized one. P-gp functions as an efflux transporter in several tissues including the gastrointestinal tract, liver, kidney, and blood-brain barrier. Inhibition or induction of P-gp (regulated by PXR or CAR $[67,68]$ ) by interacting drugs or botanical constituents may alter drug ADME resulting in significant pharmacokinetic consequences.

The inductive effect of SJW on P-gp appears to be the mechanism of interaction with known P-gp substrates. The $\mathrm{C}_{\max }$ and/or AUC values of digoxin [69,70], talinolol [71], and fexofenadine [72] were decreased after long-term administration of SJW. Supportive evidence of P-gp induction by longer SJW exposure is based on studies conducted in vitro [73,74] and in humans [75]. A 1.4fold increase in intestinal P-gp expression was observed after a 14-day administration of SJW in healthy volunteers [75]. The induction of P-gp by SJW appears to be mainly attributed to hyperforin [74].

Ginkgo biloba extract (120 mg tid for 14 or 28 days) increased the $\mathrm{C}_{\max }$ and AUC of talinolol in healthy volunteers, probably by inhibition of P-gp-mediated efflux ( $\bullet$ Tables 1 and 2) [76, 77]. On the other hand, ginkgo extract (120 mg bid, 28 days or $80 \mathrm{mg}$ tid, 7 days) failed to change the PK of digoxin [78] and fexofenadine [79]. In Caco-2 cells, ginkgo extract inhibited digoxin efflux with an $\mathrm{IC}_{50}$ of $24 \mu \mathrm{g} / \mathrm{mL}$ [80], and its flavonoids quercetin, kaempferol, and isohamnetin were shown to be P-gp substrates with inhibitory and inductive effect on P-gp [81].

Organic anion-transporting polypeptides (OATPs) are a family of transporters distributed throughout the body, including sites relevant to drug ADME (Fig. 1S). OATPs have been increasingly recognized by their contribution to drugs pharmacokinetic behavior. In the small intestine, OATP1A2 and OATP2B1 are the main OATP transporters.

Suggestion of OATPs inhibition by botanicals is demonstrated by the $85 \%, 56 \%$, and $82 \%$ decrease of OATP2B1-mediated uptake of estrone-3-sulfate by ginkgo extract [82], Echinacea purpurea extract [82], and 5\% GFJ [83], respectively, in transfected HEK293 cells. Additional data indicate that flavonoids in GFJ may be responsible for the OATP inhibition. Naringin $(50 \mu \mathrm{M})$ inhibited OATP1B1- and OATP1A2-mediated uptake of dehydroepiandrosterone sulfate [84] and fexofenadine [85], respectively; while its aglycone naringenin $(10-50 \mu \mathrm{M})$ inhibited OATP1B1- and OATP2B1-mediated influx of dehydroepiandrosterone sulfate [84] and glibenclamide [83]. Clinically, the ingestion of naringin ( $1210 \mu \mathrm{M}$ aqueous solution or $1234 \mu \mathrm{M}$ in GFJ) or GFJ resulted in 22 to 42 \% reduction in fexofenadine AUC; while a GFJ product, reported to be rich in furanocumarins, did not alter fexofenadine exposure [85]. Other OATP substrates such as etoposide, celipro- lol, and aliskiren ( Table 1) had their AUC reduced (between 85$26 \%$ ) by the co-intake of GFJ [22].

Metabolism-transport interplay: In a 2007 review, 29\% (10 out of 34) of commonly prescribed drugs with clinical evidence of botanical interaction were identified as substrates of P-gp. These include cyclosporine, digoxin, fexofenadine, imatinib, indinavir, irinotecan, nevirapine, simvastatin, saquinavir, and tacrolimus [10]. Interestingly, except digoxin and fexofenadine, these drugs are also substrates for CYP3A4. Thus, it appears that a dual substrate for CYP3A4 and P-gp has a much higher potential for interaction with botanicals. As CYP3A4 and P-gp play a role in limiting drug bioavailability after oral administration, the interdependence of metabolism and transport processes may represent a potentially important mechanism of interaction. The observed decrease of trough blood concentrations of cyclosporine, in renal or heart transplant recipients with long-term coadministration of SJW, appears to be due to an increase in both CYP3A4 activity and P-gp intestinal efflux. This botanical-mediated PK interaction was associated with the transplant graft rejection observed in all reported cases $[8,86,87]$. Similar mechanism of SJW interaction was postulated for imatinib [88,89], irinotecan [9], indinavir [90], and simvastatin [91]. An update of SJW-mediated clinical drug interactions can be found in comprehensive reviews [92, 93].

The "metabolism-transport interplay" may pose a challenge in the prediction and assessment of the specific role played by each of these mechanisms in the altered exposure of coadministered drugs [94]. For instance, assessment of preclinical and clinical data of garlic (Allium sativum) CYP3A4 and P-gp modulation raised the hypotheses of garlic affecting hepatic and intestinal enzymetransporter interplay leading to pharmacokinetic interactions. In vitro, acute exposure of the mixture of constituents of different garlic formulations (fresh, dried garlic powder, oil, and aged-garlic extract) inhibited CYP3A4 and moderately inhibited P-gp activity [25]. Allicin (diallyl thiosulfinate), found in crushed fresh garlic, inhibited CYP3A4 activity and ritonavir P-gp-mediated efflux in Caco-2 cells [95]; while garlic diallyl sulfide showed no inhibitory effect on P-gp [96]. In healthy volunteers, the $C_{\max }, C_{\min }$, and AUC of saquinavir (CYP3A4/P-gp substrate) were reduced $51 \%, 54 \%$, and $49 \%$, respectively, after garlic use (dried garlic powder GarliPure ${ }^{\circledR}, 4.64 \mathrm{mg}$ allicin and $11.2 \mathrm{mg}$ alliin, bid, 21 days). After a 10-day washout, the $C_{\max }, C_{\min }$, and AUC values were still at $60-70 \%$ of the baseline values [97]. It has been suggested that induction of CYP3A4 and/or P-gp by garlic components may represent the underlying mechanism of the altered saquinavir PK. In another interaction study in healthy volunteers, garlic supplements (using a product from the same manufacturer and dosing regimen as described above) led to a $15 \%$ decrease of saquinavir AUC [98]. To explore the causal mechanisms, the investigator further determined the expression of P-gp and CYP3A4 proteins in the duodenum and the hepatic CYP3A4 function (by erythromycin breath test). Garlic administration increased the intestinal P-gp protein levels by $31 \%$, yet no differences in the levels of CYP3A4 in the intestine and the CYP3A4 function in the liver were found. A negative correlation between changes in duodenal P-gp expression and the bioavailability of saquinavir was observed. Moreover, garlic did not alter the clearance of the CYP3A4 substrate simvastatin [98]. No effect on CYP3A4 function, evaluated by changes in the metabolic ratios of alprazolam [83] and midazolam $[45,46]$, was also observed with the use of Kwai garlic supplements (standardized on allicin potential for 14 days) or garlic oil (5 days), respectively. In contrast, no change of ritona- 
vir exposure was observed after short-term (4 days) consumption of garlic extract (Natural Source Odourless Garlic Life ${ }^{\circledR}$, $<50 \mu \mathrm{g} / \mathrm{g}$ of allicin, $10 \mathrm{mg}$ bid) by healthy volunteers [99].

These results highlight several confounding factors in the interpretation of botanical-drug interaction. First, preclinical models may not predict clinical outcomes. In vitro, aged-garlic extracts, low in alliin but rich in flavonoids, reduced saquinavir efflux by P-gp and/or MRP2 in liver models (HepG2 cells and rat liver slices) resulting in increased intracellular concentration with opposite effect (increased efflux) for darunavir [100]; whereas agedgarlic extract increased the efflux of saquinavir and darunavir in Caco-2 cells but decreased CYP3A metabolism in the rat jejune [101]. In rats, the administration of garlic oil for 5 days increased mRNA and protein levels of CYP3A1, CYP1A1, and CYP2B1 [102, 103]. The mechanism may be through activation of rat CAR [104], which regulates the expression of enzymes and drug transporters (P-gp) in the liver and intestine [33], by diallyl sulfide in garlic oil [104]. Conversely, exposure of human hepatocytes to garlic extracts $(0-200 \mu \mathrm{g} / \mathrm{mL})$ had no effect on CYP3A4 activity [105]. In combination, these results may suggest that there are interspecies differences in the regulation of CYP3A/P-gp orthologues between rodents and humans [98]. Second, a negative interaction outcome from short-term administration in humans may not represent what may be observed with prolonged use in a clinical setting. For example, the duration of garlic therapy in the ritonavir study (4 days) may have been too short to observe a significant P-gp inductive effect. Third, the composition of garlic active constituents is highly variable among different formulations ( Fig. 1 D) [106, 107]. In addition, extrapolation of the content of dried garlic powder to fresh garlic is inappropriate as the biotransformation of allicin from dried garlic supplements is extremely erratic, with the oral bioavailability of allicin varying between 5 to $95 \%$ among formulations [107]. The formulations used in the assessment of potential interactions associated with their components specific activity towards enzymes and transporters may lead to different modulating effects and ultimately different in vivo outcomes. The identification and standardization of the active constituents of botanical products are therefore essential to the evaluation of botanical-drug interactions.

Additional examples of pharmacokinetic-based interactions as a result of inhibition or induction of CYP enzymes and/or transporters are listed in $\bigcirc$ Table $\mathbf{1}$ (summary of selected clinical studies can be found in 0 Table 2). Overall, the presented examples have demonstrated that botanicals may act as modulators of drug-metabolizing enzymes and/or transporters and may have an impact on the PK of coadministered drugs which are mainly eliminated by the affected enzyme or transporter.

\section{Altered pharmacodynamics}

Pharmacodynamic interactions, although less common, can also occur, resulting in either an augmented or attenuated response. If the effect of the botanical on the coadministered drug is enhanced (e.g., by synergistic or additive effect of the drug and botanical on the same drug targets), adverse events/toxicity may occur. By contrast, some botanicals may contain compounds with antagonistic properties, which are likely to reduce drug efficacy and cause therapeutic failure.

The most commonly reported pharmacodynamic botanical-drug interactions involve antithrombotic drugs since many commonly used botanicals possess anticoagulant, antiplatelet, and/or fibrinolytic properties. In a survey of 250 patients using antithrombotic therapy, 76 were taking botanical supplements for the last
12 months. Twenty-three were taking one or more of the botanical products - Asian ginseng (Panax ginseng), garlic, and ginkgo with eight of those patients being at risk of potential botanicaldrug interactions. Interestingly, $90 \%(n=225)$ of the patients did not disclose the use of botanical supplements to their health care practitioners [108]. This example highlights the need for better education and actions to encourage communication among clinicians and patients about botanical use.

Botanicals such as Ginkgo biloba have demonstrated the potential for clinical antiplatelet activity due to the inhibition of platelet activating factor by ginkgolides [109]. Several patient cases of spontaneous bleeding (usually intracranial, intra-ocular, or postoperative) as a result of gingko use alone [110] or potential ginkgo interactions with warfarin and aspirin have been reported [111]. However, in two clinical trials, ginkgo standardized extract (EGb 761, $240 \mathrm{mg} /$ day for 7 days or $100 \mathrm{mg} /$ day for 4 weeks) failed to alter the PK and PD of warfarin in healthy subjects [60], and in patients stabilized on long-term warfarin [112]. Likewise, the concomitant use of EGb 761 (300 mg/day, 4 weeks) and aspirin did not result in enhanced inhibition of platelet function and coagulation in elderly patients at risk of cardiovascular disease [113]. Pharmacodynamic interaction studies of EGb761 with either clopidogrel or cilostazol in healthy subjects reported a nonsignificant additive effect on antiplatelet activity; although EGb761 did enhance the bleeding time prolongation effect of cilostazol [114]. It is noteworthy that the systemic levels of ginkgo active constituents were not provided in the above studies. In a PK study, the $C_{\max }$ values of ginkgolide A were 9.4 and $42.9 \mathrm{ng} /$ $\mathrm{mL}$ after oral intake of EGb 761 by elderly (120 mg) and healthy volunteers $(240 \mathrm{mg})$, respectively; whereas the $C_{\max }$ values of ginkgolide B were 6.2 and $18.2 \mathrm{ng} / \mathrm{mL}$ in elderly and healthy volunteers, respectively [115]. These systemic levels were lower than the platelet activating factor- $\mathrm{IC}_{50}$ values of 15.6 and $3.5 \mu \mathrm{g}$ / $\mathrm{mL}$ of gingkolides $\mathrm{A}$ and $\mathrm{B}$, respectively [116]. However, the marked difference of ginkgolides content among different ginkgo formulations and commercial products ( Fig. 1C) makes future extrapolation of clinical outcomes difficult.

The effect of warfarin was decreased by the coadministration of Asian ginseng (Panax ginseng) [117]. Ginseng has the potential to interfere with the coagulation cascade and therefore interact with warfarin. However, no pharmacodynamic interactions with warfarin and $P$. ginseng were observed in healthy subjects [42], patients with cardiac valve replacement [118], or with ischemic stroke [119]. The use of a different species of Panax, P. quinquefolius (American ginseng), in contrast, reduced the anticoagulant effect of warfarin in healthy adults [120]. Chemically several differences have been demonstrated between P. ginseng and P. quinquefolius, including the presence of the active constituents ginsenoside Rf in P. ginseng versus pseudoginsenoside F11 in P. quinquefolius [121]. Variation on total ginsenoside content among different commercial products of $P$. ginseng was also observed (O Fig. 1E).

Garlic could also potentially increase the effect of anticoagulant drugs as allicin has demonstrated antiplatelet activity [122]. To date, two cases have been reported in patients stabilized on warfarin who experienced doubling of international normalization ratio (INR) and had an increase in clotting time after garlic consumption (no details on dosing regimen) [123]. Similarly, there have been several reports of increased INR in patients taking warfarin and dong quai (Angelica sinensis), which also inhibits platelet aggregation; though no bleeding episodes were observed [124]. 
Potential pharmacodynamic interactions with antithrombotic drugs may occur as result of PK modulation. For example, SJW (300 mg tid, 14 days) increased the platelet inhibition effect of clopidogrel in hyporesponsive volunteers and patients via induction of CYP3A4 metabolic activity as measured by the erythromycin breath test [125]. Whether the activity of CYP2C19 was also modulated by SJW, and the contribution of CYP2C19*2 polymorphism on the response of the studied population were not evaluated.

While some botanicals have an additive effect on the pharmacological action of anticoagulants, coenzyme Q10 has demonstrated an antagonistic interaction with warfarin. A decrease in INR values below 2 was observed in three elderly patients who were stabilized on warfarin and concomitantly using $30 \mathrm{mg} / \mathrm{day}$ of coenzyme Q10 (ubidecarenone). The structural similarity of coenzyme Q10 to vitamin $K_{2}$ may suggest the enhanced coagulation effect of the coenzyme Q10 [126].

Overall, the impact of botanical supplements on normal hemostasis and antithrombotic therapy should be given careful consideration. Gingko and garlic are examples of botanicals in which precautionary use is recommended in anticoagulants/antiplatelet drug labels as it might pose an additive risk of bleeding, whereas ginseng and coenzyme Q10 may have an antagonist effect [127].

Cases of pharmacodynamic interactions with botanicals and drugs acting on the central nervous system (CNS) have been widely reported. For example, concurrent use of SJW, the most commonly used botanical antidepressant [128], with serotonergic drugs, such as selective serotonin-reuptake inhibitors (e.g., sertraline [129], fluoxetine [130], paroxetine [131], and nefazodone [132]) and serotonin agonists (e.g., buspirone [133]), caused manic episode or serotonin syndrome in some patients. The probable mechanism of interaction was an additive serotonergic effect due to the inhibitory activity of SJW on serotonin re-uptake transporters in the CNS [134].

Kava (Piper methysticum), a popular botanical with anxiolytic and sedative properties, has demonstrated additive effect with the benzodiazepine levodopa [135]. The observed increase in the duration and number of "off" periods in Parkinson's patients may be attributed to the dopamine antagonistic effect of kava extract and/or kavalactones [136]. Besides the synergistic effect at gamma-aminobutyric acid (GABA) receptors, inhibition of drugmetabolizing enzymes, such as CYP3A4 $[137,138]$ may explain the enhanced CNS-depressant effect of alprazolam resulting in a semicomatose state when kava was taken concomitantly [139]. The FDA has issued a consumer advisory about kava use [140] in the face of safety concerns that have been raised about kava hepatotoxicity [141].

Other examples of adverse events as a result of botanicals-CNS drugs pharmacodynamic interactions include reports of a patient manic episode after concomitant use of phenelzine and ginseng [142] and a possible PK/PD interaction of ginkgo with trazodone which led to an elderly patient's comatose state [143].

Although most pharmacodynamic interactions reported in the literature and reviewed in this work focused on adverse events, not all interactions will result in an undesirable effect. For example, investigators of a clinical trial claimed beneficial effects of milk thistle extract ( $140 \mathrm{mg}$ tid, 3 months), a strong antioxidant with iron chelating activity, in combination with desferrioxamine. The combined botanical-drug therapy was more effective than desferrioxamine alone in reducing serum ferritin levels in patients with beta-thalassemia major. It was suggested that sily- marin and desferrioxamine could be used safely and effectively in the treatment of iron-loaded patients [144].

There was also a report of an interaction between chlorpropamide and karela (Momordica charantia), a fruit widely consumed in Asia, Africa, and the Caribbean and used for management of type 2 diabetes mellitus as an Ayurvedic medicine. A patient whose blood glucose levels was poorly controlled when taking chlorpropamide alone, experienced a better outcome with coadministered karela [145]. Many botanicals such as Salacia oblonga [146] and Cajanus cajan [147] have shown hypoglycemic effects in animal models and in a limited number of studies in healthy adults. Since hypoglycemic agents tend to have additive effects when taken concomitantly, the potential for interaction affecting diabetic control and resulting in serious adverse events is high.

The clinical implications of any drug interactions depend on a variety of patient-dependent factors such as age, sex, nutrition habits, health status, genetic factors and metabolizing capacity, coadministered drugs and applied dosage regimens. Botanical- dependent factors include the species, dosing regimen, and composition of active constituents [148]. Nonetheless, altered pharmacokinetics almost inevitably leads to a significant change in response of a narrow therapeutic index-drug possibly resulting in serious or life-threatening adverse effects.

\section{Evaluating Botanical-Drug Interaction}

$\nabla$

Considerable effort has been focused on understanding and predicting the modulation of enzymes and transporters in vivo. A collection of gene- and protein-based assays has been used to identify the specific phase I/II enzymes and transporters involved in drug ADME, and ultimately, predict potentially significant drug interactions. Identification of the extent of metabolism by a specific enzyme and its affinity by a specific transporter is required for all new drugs by the FDA. In addition, the potency of enzyme inhibition or induction and transporter inhibition is required to be quantified [149]. These in vitro techniques may also be useful to provide mechanistic information and better characterize the active components of botanicals that have potential for drug interaction.

In silico mechanistic models, such as physiologically-based pharmacokinetic (PBPK), may be a useful tool for the prediction of potential botanical-drug interactions and evaluation of various clinical situations, including the existence of multiple patient factors (complex scenarios) such as genetic polymorphisms of certain metabolizing enzymes and disease states. PBPK simulations may also offer valuable insight into optimizing the design of interaction trials. Besides in vitro drug interaction data, sufficient information of clinical pharmacology (e.g., ADME) of both the victim drug and the enzyme/transporter modulators of botanicals need to be collected to develop PBPK models [150]. One example of PBPK application in this area is the investigation of GJF-mediated interactions with CYP3A substrates. The impact of intestinal CYP3A inhibition by GFJ 6',7'-dihydroxybergamottin on the first-pass elimination of midazolam and simvastatin has been predicted by PBPK simulations [151].

Animal models (e.g., normal, transgenic, or humanized animals) are widely used and may also provide valuable information regarding the potential for in vivo botanical-drug interactions. However, animal studies alone are not predictive of human interactions because of species differences in pharmacokinetics, sub- 
strate metabolic routes and rates, proteins specificity, and inhibitor selectivity [152].

Well-designed clinical studies using specific CYP and P-gp probes [149] in healthy volunteers or patients may generate the most clinically relevant interaction data. Trials using CYP probe cocktails have been explored to efficiently quantify the potential for interactions. Several botanicals have been evaluated in this fashion, including Echinacea [153], saw palmetto (Serenoa repens) [153], SJW [45, 52], kava [29], goldenseal [29], black cohosh [29], garlic [46, 154], valerian [29], and ginkgo [45] (0 Tables 1 and 2).

\section{Challenges of predicting botanical-drug interaction}

Lack of standardization of the active constituents: Unlike chemically defined drugs, botanicals are mostly complex mixtures of multiple active constituents with potentially different, and often unknown, mechanisms of action and modulating effects on enzymes and transporters. An array of intrinsic (e.g., plant species, organ specificity, seasonal variation) and extrinsic (e.g., environment and cultivation methods, manufacturing processes, contamination) factors greatly define botanical products composition and quality. It has been demonstrated, for example, that the content of malonyl ginsenosides in the same sample of Panax ginseng roots ranged from $0 \%$ to $1.35 \%$ using different extraction methods and decreased with increasing storage time. Additionally, the total ginsenosides were underestimated and determined imprecisely by ignoring the presence of malonyl ginsenosides [155]. The concentration variability of the marker constituents (i.e., chemically based standardization) of commonly used botanicals in the US from different formulations, manufacturers, or even batch-to-batch is illustrated in $\bigcirc$ Fig. 1. Similarly, in a study commissioned by the FDA in 1999 , only $46 \%$ and $12-24 \%$ of botanical products and extracts, respectively, were consistent with the ingredients listed in the label [156].

To mitigate botanical product quality issues, as of June 2010, manufacturers and distributors in the US are required to manufacture, label and store products in compliance with good manufacturing practices [157]. One hundred percent identity testing of components is required, unless an exemption is granted based on data that showed that less than $100 \%$ identity testing will not diminish the assurance of correct components [158]. The FDA will also inspect manufacturing facilities and carefully monitor production and labeling to ensure that the product is packaged and labeled as specified in the master manufacturing record [157]. While GMP protocols will provide at least that a predetermined amount of a marker constituent is present in each botanical product from the same manufacturer, one specific product may have a different profile of constituents than another from a different source ( $\boldsymbol{\otimes}$ Fig. $\mathbf{1}$ ) given the poorly standardized manufacturing process among producers. Therefore, extrapolation of scientific data or findings is difficult or even impossible.

Furthermore, the presence of specific concentrations of marker compounds may not guarantee enzyme/transporter modulation or pharmacologic activity. For example, commercially available SJW products used in most clinical studies are usually standardized to a fixed content of hypericin ( $\mathbf{O}$ Fig. 1 B); however, hyperforin is the active constituent responsible for CYP3A4 induction $[35,36]$. Different commercial preparations and dry extracts of SJW showed diverse PXR-mediated induction of CYP3A4, with enzyme induction magnitude being correlated to the content of hyperforin in the extract, but not hypericin and flavonoids [159]. Moreover, SJW extracts with low hyperforin content (less than $1 \mathrm{mg}$ daily) have not demonstrated any clinically relevant interactions, including with CYP3A4 and P-gp drug substrates $[51,160-163]$. As demonstrated in O Fig. 1B, the measured amounts of hypericin and hyperforin varied considerably among different manufacturers.

For effective botanical-drug interaction evaluation in clinical settings, researchers must be aware of the aforementioned quality issues. Proper identification of the botanical (Latin binomial and authority) and the part(s) used in the preparation of the product including the processes used to extract and isolate the purported active constituents is the first step to ensure some minimal characterization of botanical products and define a potential botanical-drug interaction [164]. The content of the purported perpetrator(s) of interaction in the formulation and its systemic exposure should be measured whenever possible.

Extrapolation of results from in vitro studies: Prediction of the in vivo modulation effect of botanical products from in vitro data is usually problematic. Besides the multiplicity of constituents at variable concentrations as discussed above, the poor and/or variable absorption of the active inhibitor(s)/inducer(s) may lead to different in vivo effects. For instance, the effect of milk thistle (standardized seeds extract contains at least 30-65\% flavonolignans including the active constituents silybin A and B collectively known as silymarin) on several enzymes and transporters has shown a conflicting in vitro/in vivo correlation. While a dose-dependent inhibitory effect of silymarin or silybin on various CYP isoforms, including CYP3A4 $\left(\mathrm{K}_{\mathrm{i}}\right.$ range $\left.=5-160 \mu \mathrm{M}\right)$ and CYP2C9 $\left(\mathrm{K}_{\mathrm{i}}\right.$ range $\left.=5-19 \mu \mathrm{M}\right)$ was observed in several in vitro studies [17, 165-167], the PK of CYP3A4 substrates nifedipine [168] and midazolam [153] were not affected by silymarin co-treatment $(560 \mathrm{mg} /$ day for 1 day and $175 \mathrm{mg}$ of standardized extract to $80 \%$ silymarin, bid, 28 days, respectively) in healthy volunteers. On the contrary, a CYP2C9 genotype-dependent interaction between losartan (CYP2C9/CYP3A substrate) and silymarin ( $420 \mathrm{mg} /$ day for 14 days) was demonstrated [169]. Regarding transport modulation, silymarin $(50 \mu \mathrm{M})$ decreased $\left[{ }^{3} \mathrm{H}\right]$ dehydroepiandrosterone (DHEA) uptake in OATP-B1-expressing cells [84] and increased the intracellular accumulation of $\left[{ }^{3} \mathrm{H}\right]$ daunomycin (P-gp substrate) and mitoxantrone (BCRP substrate) in P-gp- [170] and BCRP- [171] overexpressing cells; although silymarin $(7 \mu \mathrm{g} / \mathrm{mL}-2 \mathrm{ng} / \mathrm{mL}$ of silybin) had no effect on P-gp activity in Caco-2 cells [28]. In healthy volunteers, on the other hand, no changes in the PK of rosuvastatin (OATP1B1/BCRP substrate; not extensively metabolized) were observed with silymarin cotreatment (520 mg/day for 3 days) [172]. Likewise, silymarin did not alter the PK of digoxin [173] (900 mg/day for 14 days) and the dual CYP3A4/P-gp substrates indinavir [174-176] and ranitidine [177], while the oral clearance of metronidazole and its major metabolite was increased by $30 \%$ and $\mathrm{C}_{\max }$ and AUC decreased by silymarin coadministration (140 mg/day for 9 days) [178]. This discrepancy may be caused by the low bioavailability $(\sim 1 \%)$ of the commercially available formulations of milk thistle [179, 180] used in the clinical studies. As such, sufficient systemic concentrations of the inhibitors (active flavonolignans) may not be reached. For instance, the maximum plasma concentration of total (free and conjugated) silybin achieved after ingestion of $600 \mathrm{mg}$ milk thistle extract (57\% silybin) was around $0.4 \mu \mathrm{M}$ [181] which is below the lower end of the inhibition constants of CYP2C9 and CYP3A4 $(\mathrm{Ki}=5 \mu \mathrm{M})$ [17,165-167]. Additionally, the oral bioavailability of flavonolignans is highly variable [180]. Potential inter-product variation of the active constituents may also occur, which can confound the interpretation of study results. 
Differential effect on intestinal and hepatic CYP3A: The potential for a differential effect of a botanical constituent on intestinal and hepatic CYP3A makes the prediction of botanical interactions with CYP3A substrates difficult. For instance, the activity of CYP3A at intestinal and hepatic sites was selectively modulated by Echinacea purpurea ( $400 \mathrm{mg}$, qid, 8 days) in healthy subjects. The intestinal availability of oral-administered midazolam was increased by $85 \%$ as result of inhibited intestinal CYP3A, but the oral clearance was not altered. Conversely, the systemic clearance of intravenous midazolam, a reflection of hepatic CYP3A activity, was increased by $34 \%$ [182]. A subsequent trial reported no effect of E. purpurea $(1600 \mathrm{mg} /$ day) on the activity of CYP3A with the probe midazolam dosed orally [153]. Therefore, the prediction of whether Echinacea interaction will result in inhibition or induction of CYP3A activity will be dependent on the hepatic and intestinal extraction ratios of the interacting CYP3A substrate [182]. For instance, drugs with minimal first-pass metabolism may demonstrate an increased oral clearance due to the induction of hepatic CYP3A; whereas drugs with high first-pass elimination may demonstrate increased exposure ( $C_{\max }$ and/or AUC) due to the inhibition of intestinal CYP3A.

Single-dose administration vs. multiple dosing: Because of the biphasic effect of some botanicals, results from single-dose studies may be different from chronic dosing, as exemplified by several reported interactions indicating that inhibition and induction mechanisms depend on the exposure time. For example, differential SJW effects on CYPs and/or P-gp between short-time (1-3 days) versus chronic administration ( $>14$ days) have been observed [183]. While SJW (900 mg/day) did not alter the pharmacokinetics of the CYP3A4 probes midazolam [50] and alprazolam [184] when administered to healthy volunteers for 2 or 3 days, respectively, the oral clearance of midazolam was increased after 14 days administration $(900 \mathrm{mg})[50,185]$. Another example, a $43 \%$ reduction of voriconazole AUC (CYP2C19/CYP2C9/CYP3A4 substrate) was observed after SJW exposure (300 mg extract) for 15 days, whereas short-term dosing resulted in a $22 \%$ increase of voriconazole AUC [58]. Similar effect is observed in regard to SJW modulation of P-gp. A single dose of SJW (Sundown ${ }^{\circledR}, 900 \mathrm{mg}$ ) increased $C_{\max }$ and decreased $\mathrm{CL} / \mathrm{F}$ of fexofenadine by $45 \%$ and $20 \%$, respectively, indicating an inhibition of intestinal P-gp activity; while the long-term administration of SJW (900 mg/day, 14 days) did not alter fexofenadine disposition relative to an untreated period [72]. Conversely, in another study with the same SJW dose (Jarsin $300^{\circledR} 900 \mathrm{mg} /$ day, 14 days) a $35 \%$ decrease in $C_{\max }$ and $47 \%$ increase in $\mathrm{CL} / \mathrm{F}$ of fexofenadine was observed, possibly as a result of P-gp induction [186].

Effect of patient-intrinsic factors: Patient-related factors including genetic polymorphisms of CYPs and genes that encode transporters, such as MDR1 for P-gp, may contribute to the net outcome of a drug interaction. As such, botanical-drug interactions via metabolic or transport pathways also have the potential to be influenced by genetic factors. Genetic information has been incorporated in study designs to explore the interplay of genetic polymorphisms and combined use of botanical products. For example, the technique of gene expression profiling in rodent liver has been applied to identify the genetic mutations in metabolic pathways influenced by botanicals and facilitate more precise targeting of human studies [187]. Pharmacogenomic studies in humans may help to identify the interactions which may be more pronounced or only occur in specific groups of subjects. For example, the effects of coadministered milk thistle extract $(420 \mathrm{mg} /$ day of silymarin, 14 days) on the PK of losartan
(CYP2C9/CYP3A substrate) and its active metabolite E-3174 were investigated in CYP2C9 genotyped healthy men. In both CYP2C9 wild-type and CYP2C9*1/*3 carriers, silymarin decreased the AUC of E-3174 while increasing the AUC of losartan. The losartan metabolic ratio was reduced in CYP2C9 wild-type subjects but not in those with CYP2C9* $1{ }^{*} 3$ genotype. Thus, silymarin inhibited the metabolism of losartan to E-3174, and the magnitude of the interaction was dependent on CYP2C9 genotype [169]. Likewise, ginkgo has demonstrated modulation of CYP2C19 expression and activity in a genotype-dependent manner [188] (O Table 2).

\section{Botanical Products: Regulatory Perspectives \\ $\nabla$}

In the United States, most botanicals are sold as dietary supplements. The 1994 Dietary Supplement Health and Education Act (DSHEA) provides regulatory framework for the safety and labeling of dietary supplements [189], defined as products taken by mouth that contain a "dietary ingredient" intended to supplement the diet. Dietary ingredients include herbs or other botanicals, vitamins, minerals, and amino acids. For a new dietary ingredient (NDI), a pre-market review of safety data is required by law [189]; otherwise, manufactures are exempted to provide the FDA with the evidence it relies on to substantiate safety or effectiveness. The majority of FDA's efforts related to dietary supplement safety are focused on the post-marketing period as postmarketing surveillance is mandatory under the 2006 Dietary Supplement and Nonsprescription Drug Consumer Protection Act [190]. By law, manufactures and distributors of dietary supplements are required to record and report to the FDA (MedWatch program-form 3500A), in a timely manner, information about serious adverse events associated with the use of their products that are reported directly to them [190]. The FDA Adverse Event Reporting program, mandatory and voluntary (by consumers and practitioners), provides initial signaling of safety issues, including the occurrence of drug interactions with botanical products. Additional clinical and scientific information are further compiled to serve as the basis of FDA risk mitigation actions, which includes education of the public and labeling language on prescription drug products $[149,191]$.

To address practitioners and consumers concerns about the quality of dietary supplements, good manufacturing practice regulations were established in 2007 and became effective in 2010. Manufactures and distributors must comply with the Current Good Manufacturing Practices (cGMPs) in Manufacturing, Packaging, Labeling, or Holding Operations for Dietary Supplements [157] by adhering to a specific set of manufacturing processes, safety procedures, and packing and labeling standards to guarantee the identity, purity, strength, and composition of dietary supplements.

In 2004, the FDA published the guidance "Botanical Drug Products" to facilitate and encourage development of "new botanical drug products" [192]. The guidance describes the requirements of appropriateness of clinical efficacy and safety data, and of clinical pharmacology investigations including bioavailability and interactions between botanicals and commonly used drugs and/or dietary supplements. Chemistry/Manufacturing control procedures are also recommended. To the end of 2008, a total of 350 pre-investigational and investigational new drug applications of botanical drug products had been submitted to the Agency [193]. 


\section{Botanical-drug interaction: labeling implications}

Regulations of prescription drug labeling requires that drugs or food that interact in clinically significant ways with the product should be referenced in the "Highlights - Drug Interactions" section of its labeling [191]. Depending on the potential clinical consequences of an interaction, essential information for health care practitioners may be stated in the "Drug Interactions", "Dosage and Administration", "Contraindications", "Warnings and Precautions", and "Clinical Pharmacology" sections of the prescription drug label. Additionally, the 2012 FDA draft-guidance entitled "Guidance for industry: Drug interaction studies - study design, data analysis and implications for dosing and labeling" proposed a classification system for CYP inhibitors and inducers in the labeling, in an effort to improve the consistency of labeling language [149].

Labeling decisions for interactions with SJW or GFJ can be based on the metabolic and dispositional characteristics of the drugs being labeled without conducting actual in vivo studies to characterize the interaction. For example, if a drug is a substrate for either CYP3A or P-gp, or both, and modulation (induction) of these pathways may significantly decrease drug systemic exposure and effectiveness, cautions regarding the use of SJW are added to the label. Representative examples of drugs with labeling warnings about SJW use are listed in Table 1S. If a CYP3A substrate drug also has a low oral bioavailability because of extensive first-pass metabolism by intestinal CYP3A4, warnings regarding concomitant ingestion of grapefruit juice may be added to the label, depending on the drug's exposure-response relationship. For example, labeling for simvastatin and dasatinib carry warnings about GFJ use (Table 1S). Additionally, some SJW products carry warning language about potential drug interactions (Table 2S).

\section{Conclusions and Future Perspectives $\nabla$}

Drug interactions with botanicals have been increasingly reported. Timely identification of drugs that may interact with botanical's active constituents and the mechanism involved is essential for better clinical risk assessment. Researchers and manufacturers of botanical products are encouraged to fully apply the available guidelines and tools to evaluate potential botanicaldrug interactions. Meaningful botanical-drug interaction monitoring should take into account inherent quality issues of botanicals, patient factors, and clinical experimental design. To better translate information into practice, regulations on prescription drug labeling content and format were set in place to highlight key drug interactions. New drugs that are CYP3A and/or P-gp substrates have higher potential for drug interactions, which may lead to labeling language regarding concomitant use with botanicals such as St. John's wort and grapefruit juice. Another risk management strategy includes mandatory reporting by manufacturers and distributors of any serious adverse events associated with the use of their botanical products. Assurance of product quality is enforced by the recent implemented cGMP regulations for dietary supplements. Strategies to strengthen knowledge and to facilitate communications among patients and clinicians about botanicals and potential interactions are also encouraged. With continued improvement in our understanding of the mechanism of drug interactions, the risks associated with such can be better predicted, evaluated and managed, in order to reduce the propensity of clinical significant adverse interactions.

\section{Supporting information}

Tables summarizing labeling examples of drug interactions involving St. John's wort or grapefruit products and of selected St. John's wort products, as well as a figure illustrating examples of efflux and uptake transporters in the gut wall, liver, and kidneys are available as Supporting Information.

\section{Acknowledgements \\ $\nabla$}

The authors acknowledge the CAPES/Fulbright program for the doctoral scholarship of M. Vieira. This work was supported in part by an appointment to the Research Participation Program at the Center for Drug Evaluation and Research administered by Oak Ridge Institute for Science and Education through an interagency agreement between the US Department of Energy and US Food and Drug Administration.

\section{Disclaimer \\ $\nabla$}

The views presented in this manuscript are the author's and do not necessarily reflect those of the US Food and Drug Administration.

\section{Conflict of Interest \\ $\nabla$}

The authors declared no conflict of interest.

\section{References}

1 American Botanical Council. Herbal supplements sale rise in all channels in 2009. Herbalgram 2010; 86: 62-65

2 Bardia A, Nisly NL, Zimmerman MB, Gryzlak BM, Wallace RB. Use of herbs among adults based on evidence-based indications: findings from the National Health Interview Survey. Mayo Clin Proc 2007; 82: 561-566

3 Bent S. Herbal medicine in the United States: review of efficacy, safety, and regulation: grand rounds at University of California, San Francisco Medical Center. J Gen Intern Med 2008; 23: 854-859

4 Hensrud DD, Engle DD, Scheitel SM. Underreporting the use of dietary supplements and nonprescription medications among patients undergoing a periodic health examination. Mayo Clin Proc 1999; 74: 443447

5 Ernst E. Herb-drug interactions: potentially important but woefully under-researched. Eur J Clin Pharmacol 2000; 56: 523-524

6 Dodge T, Litt D, Kaufman A. Influence of the dietary supplement health and education act on consumer beliefs about the safety and effectiveness of dietary supplements. J Health Commun 2011; 16: 230-244

7 Fugh-Berman A. Herb-drug interactions. Lancet 2000; 355: 134-138

8 Ruschitzka F, Meier PJ, Turina M, Luscher TF, Noll G. Acute heart transplant rejection due to Saint John's wort. Lancet 2000; 355: 548-549

9 Mathijssen RH, Verweij J, de Bruijn P, Loos WJ, Sparreboom A. Effects of St. John's wort on irinotecan metabolism. J Natl Cancer Inst 2002; 94: $1247-1249$

10 Zhou SF, Zhou ZW, Li CG, Chen X, Yu X, Xue CC, Herington A. Identification of drugs that interact with herbs in drug development. Drug Discov Today 2007; 12: 664-673

11 Wienkers $L C$, Heath TG. Predicting in vivo drug interactions from in vitro drug discovery data. Nat Rev Drug Discov 2005; 4: 825-833

12 Lam Y, Huang SM, Hall SD. Drug interactions with botanical products. In: Lam Y, Huang S, Hall S, editors. Herbal supplements-drug interactions - Scientific and regulatory perspectives. Drugs and the pharmaceutical sciences. New York: Taylor \& Francis; 2006: 25-47

13 Guillemette C. Pharmacogenomics of human UDP-glucuronosyltransferase enzymes. Pharmacogenomics J 2003; 3: 136-158 
14 Obach RS, Walsky RL, Venkatakrishnan K. Mechanism-based inactivation of human cytochrome p450 enzymes and the prediction of drugdrug interactions. Drug Metab Dispos 2007; 35: 246-255

15 Zhou S, Koh HL, Gao Y, Gong ZY, Lee EJ. Herbal bioactivation: the good, the bad and the ugly. Life Sci 2004; 74: 935-968

16 Tarirai C, Viljoen AM, Hamman JH. Herb-drug pharmacokinetic interactions reviewed. Expert Opin Drug Metab Toxicol 2010; 6: 1515-1538

17 Sridar C, Goosen TC, Kent UM, Williams JA, Hollenberg PF. Silybin inactivates cytochromes P450 3A4 and 2C9 and inhibits major hepatic glucuronosyltransferases. Drug Metab Dispos 2004; 32: 587-594

18 Tassaneeyakul W, Guo LQ Fukuda K, Ohta T, Yamazoe Y. Inhibition selectivity of grapefruit juice components on human cytochromes P450. Arch Biochem Biophys 2000; 378: 356-363

19 Guo LQ Yamazoe Y. Inhibition of cytochrome P450 by furanocoumarins in grapefruit juice and herbal medicines. Acta Pharmacol Sin 2004; 25 : 129-136

20 Schmiedlin-Ren P, Edwards DJ, Fitzsimmons ME, He K, Lown KS, Woster PM, Rahman A, Thummel KE, Fisher JM, Hollenberg PF, Watkins PB. Mechanisms of enhanced oral availability of CYP3A4 substrates by grapefruit constituents. Decreased enterocyte CYP3A4 concentration and mechanism-based inactivation by furanocoumarins. Drug Metab Dispos 1997; 25: 1228-1233

21 Lown KS, Bailey DG, Fontana RJ, Janardan SK, Adair CH, Fortlage LA, Brown $M B$, Guo $W$, Watkins $P B$. Grapefruit juice increases felodipine oral availability in humans by decreasing intestinal CYP3A protein expression. J Clin Invest 1997; 99: 2545-2553

22 Hanley MJ, Cancalon P, Widmer WW, Greenblatt DJ. The effect of grapefruit juice on drug disposition. Expert Opin Drug Metab Toxicol 2011; 7: 267-286

23 Xin HW, Wu XC, Li Q Yu AR, Zhong MY, Liu YY. The effects of berberine on the pharmacokinetics of cyclosporin A in healthy volunteers. Methods Find Exp Clin Pharmacol 2006; 28: 25-29

$24 \mathrm{Wu}$ X, Li Q Xin H, Yu A, Zhong M. Effects of berberine on the blood concentration of cyclosporin $A$ in renal transplanted recipients: clinical and pharmacokinetic study. Eur J Clin Pharmacol 2005; 61: 567-572

25 Foster BC, Vandenhoek S, Hana J, Krantis A, Akhtar MH, Bryan M, Budzinski JW, Ramputh A, Arnason JT. In vitro inhibition of human cytochrome P450-mediated metabolism of marker substrates by natural products. Phytomedicine 2003; 10: 334-342

26 Raner GM, Cornelious S, Moulick K, Wang Y, Mortenson A, Cech NB. Effects of herbal products and their constituents on human cytochrome P450(2E1) activity. Food Chem Toxicol 2007; 45: 2359-2365

27 Etheridge AS, Black SR, Patel PR, So J, Mathews JM. An in vitro evaluation of cytochrome P450 inhibition and P-glycoprotein interaction with goldenseal, Ginkgo biloba, grape seed, milk thistle, and ginseng extracts and their constituents. Planta Med 2007; 73: 731-741

28 Budzinski JW, Trudeau VL, Drouin CE, Panahi M, Arnason JT, Foster BC. Modulation of human cytochrome P450 3A4 (CYP3A4) and P-glycoprotein (P-gp) in Caco-2 cell monolayers by selected commercialsource milk thistle and goldenseal products. Can J Physiol Pharmacol 2007; 85: 966-978

29 Gurley BJ, Gardner SF, Hubbard MA, Williams DK, Gentry WB, Khan IA, Shah A. In vivo effects of goldenseal, kava kava, black cohosh, and valerian on human cytochrome P450 1A2, 2D6, 2E1, and 3A4/5 phenotypes. Clin Pharmacol Ther 2005; 77: 415-426

30 Gurley BJ, Swain A, Hubbard MA, Williams DK, Barone G, Hartsfield F, Tong Y, Carrier DJ, Cheboyina S, Battu SK. Clinical assessment of CYP2D6-mediated herb-drug interactions in humans: effects of milk thistle, black cohosh, goldenseal, kava kava, St. John's wort, and Echinacea. Mol Nutr Food Res 2008; 52: 755-763

31 Gurley BJ, Swain A, Hubbard MA, Hartsfield F, Thaden J, Williams DK, Gentry WB, Tong Y. Supplementation with goldenseal (Hydrastis canadensis), but not kava kava (Piper methysticum), inhibits human CYP3A activity in vivo. Clin Pharmacol Ther 2008; 83: 61-69

32 Hewitt NJ, Lecluyse EL, Ferguson SS. Induction of hepatic cytochrome P450 enzymes: methods, mechanisms, recommendations, and in vitro-in vivo correlations. Xenobiotica 2007; 37: 1196-1224

33 di Masi A, De Marinis E, Ascenzi P, Marino M. Nuclear receptors CAR and PXR: Molecular, functional, and biomedical aspects. Mol Aspects Med 2009; 30: 297-343

34 Komoroski BJ, Zhang S, Cai H, Hutzler JM, Frye R, Tracy TS, Strom SC, Lehmann T, Ang CY, Cui YY, Venkataramanan R. Induction and inhibition of cytochromes $\mathrm{P} 450$ by the St. John's wort constituent hyperforin in human hepatocyte cultures. Drug Metab Dispos 2004; 32: 512-518
35 Moore LB, Goodwin B, Jones SA, Wisely GB, Serabjit-Singh CJ, Willson TM, Collins JL, Kliewer SA. St. John's wort induces hepatic drug metabolism through activation of the pregnane $X$ receptor. Proc Natl Acad Sci USA 2000; 97: 7500-7502

36 Kober M, Pohl K, Efferth T. Molecular mechanisms underlying St. John's wort drug interactions. Curr Drug Metab 2008; 9: 1027-1037

37 Wentworth JM, Agostini M, Love J, Schwabe JW, Chatterjee VK. St John's wort, a herbal antidepressant, activates the steroid $\mathrm{X}$ receptor. J Endocrinol 2000; 166: R11-R16

38 de Maat MM, Hoetelmans RM, Math $t$ RA, van Gorp EC, Meenhorst PL, Mulder JW, Beijnen JH. Drug interaction between St John's wort and nevirapine. AIDS 2001; 15: 420-421

39 Portoles A, Terleira A, Calvo A, Martinez I, Resplandy G. Effects of Hypericum perforatum on ivabradine pharmacokinetics in healthy volunteers: an open-label, pharmacokinetic interaction clinical trial. J Clin Pharmacol 2006; 46: 1188-1194

40 Kawaguchi A, Ohmori M, Tsuruoka S, Nishiki K, Harada K, Miyamori I, Yano R, Nakamura T, Masada M, Fujimura A. Drug interaction between St John's Wort and quazepam. Br J Clin Pharmacol 2004; 58: 403-410

41 Tannergren C, Engman H, Knutson L, Hedeland M, Bondesson U, Lennernas $H$. St John's wort decreases the bioavailability of R- and S-verapamil through induction of the first-pass metabolism. Clin Pharmacol Ther 2004; 75: 298-309

42 Jiang X, Williams KM, Liauw WS, Ammit AJ, Roufogalis BD, Duke CC, Day RO, McLachlan AJ. Effect of St John's wort and ginseng on the pharmacokinetics and pharmacodynamics of warfarin in healthy subjects. $\mathrm{Br}$ J Clin Pharmacol 2004; 57: 592-599

43 Hellum $\mathrm{BH}, \mathrm{Hu} \mathrm{Z}$, Nilsen OG. Trade herbal products and induction of CYP2C19 and CYP2E1 in cultured human hepatocytes. Basic Clin Pharmacol Toxicol 2009; 105: 58-63

44 Karyekar CS, Eddington ND, Dowling TC. Effect of St. John's Wort extract on intestinal expression of cytochrome P4501A2: studies in LS180 cells. J Postgrad Med 2002; 48: 97-100

45 Gurley BJ, Gardner SF, Hubbard MA, Williams DK, Gentry WB, Cui Y, Ang $C Y$. Clinical assessment of effects of botanical supplementation on cytochrome P450 phenotypes in the elderly: St John's wort, garlic oil, Panax ginseng and Ginkgo biloba. Drugs Aging 2005; 22: 525-539

46 Gurley BJ, Gardner SF, Hubbard MA, Williams DK, Gentry WB, Cui Y, Ang $C Y$. Cytochrome $\mathrm{P} 450$ phenotypic ratios for predicting herb-drug interactions in humans. Clin Pharmacol Ther 2002; 72: 276-287

47 Wang LS, Zhu B, Abd El-Aty AM, Zhou G, Li Z, Wu J, Chen GL, Liu J, Tang ZR, An W, Li Q Wang D, Zhou HH. The influence of St John's Wort on CYP2C19 activity with respect to genotype. J Clin Pharmacol 2004; 44: 577-581

48 Wang LS, Zhou G, Zhu B, Wu J, Wang JG, Abd El-Aty AM, Li T, Liu J, Yang TL, Wang D, Zhong XY, Zhou HH. St John's wort induces both cytochrome P450 3A4-catalyzed sulfoxidation and 2C19-dependent hydroxylation of omeprazole. Clin Pharmacol Ther 2004; 75: 191-197

49 Xu H, Williams KM, Liauw WS, Murray M, Day RO, McLachlan AJ. Effects of St John's wort and CYP2C9 genotype on the pharmacokinetics and pharmacodynamics of gliclazide. Br J Pharmacol 2008; 153: 15791586

50 Wang Z, Gorski JC, Hamman MA, Huang SM, Lesko LJ, Hall SD. The effects of St John's wort (Hypericum perforatum) on human cytochrome P450 activity. Clin Pharmacol Ther 2001; 70: 317-326

51 Arold G, Donath F, Maurer A, Diefenbach K, Bauer S, Henneicke-von Zepelin $H H$, Friede $M$, Roots I. No relevant interaction with alprazolam, caffeine, tolbutamide, and digoxin by treatment with a low-hyperforin St John's wort extract. Planta Med 2005; 71: 331-337

52 Wenk M, Todesco L, Krahenbuhl S. Effect of St John's wort on the activities of CYP1A2, CYP3A4, CYP2D6, N-acetyltransferase 2, and xanthine oxidase in healthy males and females. Br J Clin Pharmacol 2004; 57 : 495-499

53 Nebel A, Schneider BJ, Baker RK, Kroll DJ. Potential metabolic interaction between St. John's wort and theophylline. Ann Pharmacother 1999; 33: 502

54 de los Reyes GC, Koda RT. Determining hyperforin and hypericin content in eight brands of St. John's wort. Am J Health Syst Pharm 2002; 59: 545-547

55 Krochmal R, Hardy M, Bowerman S, Lu OY, Wang HJ, Elashoff R, Heber D. Phytochemical assays of commercial botanical dietary supplements. Evid Based Complement Alternat Med 2004; 1: 305-313

56 Obach RS. Inhibition of human cytochrome P450 enzymes by constituents of St. John's Wort, an herbal preparation used in the treatment of depression. J Pharmacol Exp Ther 2000; 294: 88-95 
57 Hellum BH, Nilsen OG. The in vitro inhibitory potential of trade herbal products on human CYP2D6-mediated metabolism and the influence of ethanol. Basic Clin Pharmacol Toxicol 2007; 101: 350-358

58 Rengelshausen J, Banfield M, Riedel KD, Burhenne J, Weiss J, Thomsen T, Walter-Sack I, Haefeli WE, Mikus G. Opposite effects of short-term and long-term St John's wort intake on voriconazole pharmacokinetics. Clin Pharmacol Ther 2005; 78: 25-33

59 Mohutsky MA, Anderson GD, Miller JW, Elmer GW. Ginkgo biloba: evaluation of CYP2C9 drug interactions in vitro and in vivo. Am J Ther 2006; 13: $24-31$

60 Jiang X, Williams KM, Liauw WS, Ammit AJ, Roufogalis BD, Duke CC, Day $R O$, McLachlan AJ. Effect of ginkgo and ginger on the pharmacokinetics and pharmacodynamics of warfarin in healthy subjects. Br J Clin Pharmacol 2005; 59: 425-432

61 Kim BH, Kim KP, Lim KS, Kim JR, Yoon SH, Cho JY, Lee YO, Lee KH, Jang IJ, Shin SG, Yu KS. Influence of Ginkgo biloba extract on the pharmacodynamic effects and pharmacokinetic properties of ticlopidine: an openlabel, randomized, two-period, two-treatment, two-sequence, singledose crossover study in healthy Korean male volunteers. Clin Ther 2010; 32: 380-390

62 Uchida S, Yamada H, Li XD, Maruyama S, Ohmori Y, Oki T, Watanabe H, Umegaki K, Ohashi K, Yamada S. Effects of Ginkgo biloba extract on pharmacokinetics and pharmacodynamics of tolbutamide and midazolam in healthy volunteers. J Clin Pharmacol 2006; 46: 1290-1298

63 Liu XP, Goldring CE, Wang HY, Copple IM, Kitteringham NR, Park BK. Extract of Ginkgo biloba induces glutathione-S-transferase subunit-P1 in vitro. Phytomedicine 2009; 16: 451-455

64 Sugiyama T, Kubota Y, Shinozuka K, Yamada S, Yamada K, Umegaki K. Induction and recovery of hepatic drug metabolizing enzymes in rats treated with Ginkgo biloba extract. Food Chem Toxicol 2004; 42: 953957

65 Mohamed MF, Frye RF. Inhibition of intestinal and hepatic glucuronidation of mycophenolic acid by Ginkgo biloba extract and flavonoids. Drug Metab Dispos 2010; 38: 270-275

66 van Erp NP, Baker SD, Zhao M, Rudek MA, Guchelaar HJ, NortierJW, Sparreboom A, Gelderblom $\mathrm{H}$. Effect of milk thistle (Silybum marianum) on the pharmacokinetics of irinotecan. Clin Cancer Res 2005; 11: 78007806

67 Marchetti S, Mazzanti R, Beijnen JH, Schellens JH. Concise review: Clinical relevance of drug drug and herb drug interactions mediated by the ABC transporter ABCB1 (MDR1, P-glycoprotein). Oncologist 2007; 12: 927-941

68 Matic M, Mahns A, Tsoli M, Corradin A, Polly P, Robertson GR. Pregnane X receptor: promiscuous regulator of detoxification pathways. Int J Biochem Cell Biol 2007; 39: 478-483

69 Dasgupta A. Herbal supplements and therapeutic drug monitoring: focus on digoxin immunoassays and interactions with St. John's wort. Ther Drug Monit 2008; 30: 212-217

70 Mueller SC, Uehleke B, Woehling H, Petzsch M, Majcher-Peszynska J, Hehl EM, Sievers H, Frank B, Riethling AK, Drewelow B. Effect of St John's wort dose and preparations on the pharmacokinetics of digoxin. Clin Pharmacol Ther 2004; 75: 546-557

71 Schwarz UI, Hanso H, Oertel R, Miehlke S, Kuhlisch E, Glaeser H, Hitzl M, Dresser GK, Kim RB, Kirch W. Induction of intestinal P-glycoprotein by St John's wort reduces the oral bioavailability of talinolol. Clin Pharmacol Ther 2007; 81: 669-678

72 Wang Z, Hamman MA, Huang SM, Lesko LJ, Hall SD. Effect of St John's wort on the pharmacokinetics of fexofenadine. Clin Pharmacol Ther 2002; 71: 414-420

73 Tian R, Koyabu N, Morimoto S, Shoyama Y, Ohtani H, Sawada Y. Functional induction and de-induction of P-glycoprotein by St. John's wort and its ingredients in a human colon adenocarcinoma cell line. Drug Metab Dispos 2005; 33: 547-554

74 Gutmann H, Poller B, Buter KB, Pfrunder A, Schaffner W, Drewe J. Hypericum perforatum: which constituents may induce intestinal MDR1 and CYP3A4 mRNA expression? Planta Med 2006; 72: 685-690

75 Durr D, Stieger B, Kullak-Ublick GA, Rentsch KM, Steinert HC, Meier PJ, Fattinger K. St John's Wort induces intestinal P-glycoprotein/MDR1 and intestinal and hepatic CYP3A4. Clin Pharmacol Ther 2000; 68: 598-604

76 Fan L, Mao XQ Tao GY, Wang G, Jiang F, Chen Y, Li Q Zhang W, Lei HP, Hu DL, Huang YF, Wang D, Zhou HH. Effect of Schisandra chinensis extract and Ginkgo biloba extract on the pharmacokinetics of talinolol in healthy volunteers. Xenobiotica 2009; 39: 249-254
77 Fan L, Tao GY, Wang G, Chen Y, Zhang W, He YJ, Li Q Lei HP, Jiang F, Hu DL, Huang YF, Zhou HH. Effects of Ginkgo biloba extract ingestion on the pharmacokinetics of talinolol in healthy Chinese volunteers. Ann Pharmacother 2009; 43: 944-949

78 Mauro VF, Mauro LS, Kleshinski JF, Khuder SA, Wang Y, Erhardt PW. Impact of Ginkgo biloba on the pharmacokinetics of digoxin. Am J Ther 2003; 10: 247-251

79 Robertson SM, Davey RT, Voell J, Formentini E, Alfaro RM, Penzak SR. Effect of Ginkgo biloba extract on lopinavir, midazolam and fexofenadine pharmacokinetics in healthy subjects. Curr Med Res Opin 2008; 24: 591-599

80 Hellum BH, Nilsen OG. In vitro inhibition of CYP3A4 metabolism and Pglycoprotein-mediated transport by trade herbal products. Basic Clin Pharmacol Toxicol 2008; 102: 466-475

81 Wang Y, Cao J, Zeng S. Involvement of P-glycoprotein in regulating cellular levels of Ginkgo flavonols: quercetin, kaempferol, and isorhamnetin. J Pharm Pharmacol 2005; 57: 751-758

82 Fuchikami H, Satoh H, Tsujimoto M, Ohdo S, Ohtani H, Sawada Y. Effects of herbal extracts on the function of human organic anion-transporting polypeptide OATP-B. Drug Metab Dispos 2006; 34: 577-582

83 Satoh H, Yamashita F, Tsujimoto M, Murakami H, Koyabu N, Ohtani $H$, Sawada Y. Citrus juices inhibit the function of human organic aniontransporting polypeptide OATP-B. Drug Metab Dispos 2005; 33: 518523

84 Wang X, Wolkoff AW, Morris ME. Flavonoids as a novel class of human organic anion-transporting polypeptide OATP1B1 (OATP-C) modulators. Drug Metab Dispos 2005; 33: 1666-1672

85 Bailey DG, Dresser GK, Leake BF, Kim RB. Naringin is a major and selective clinical inhibitor of organic anion-transporting polypeptide $1 \mathrm{~A} 2$ (OATP1A2) in grapefruit juice. Clin Pharmacol Ther 2007; 81: 495-502

86 Alscher DM, Klotz U. Drug interaction of herbal tea containing St. John's wort with cyclosporine. Transpl Int 2003; 16: 543-544

87 Bauer S, Stormer E, Johne A, Kruger H, Budde K, Neumayer HH, Roots I, Mai I. Alterations in cyclosporin A pharmacokinetics and metabolism during treatment with St John's wort in renal transplant patients. Br J Clin Pharmacol 2003; 55: 203-211

88 Frye RF, Fitzgerald SM, Lagattuta TF, Hruska MW, Egorin MJ. Effect of St John's wort on imatinib mesylate pharmacokinetics. Clin Pharmacol Ther 2004; 76: 323-329

89 Smith P, Bullock JM, Booker BM, Haas CE, Berenson CS, Jusko WJ. The influence of St. John's wort on the pharmacokinetics and protein binding of imatinib mesylate. Pharmacotherapy 2004; 24: 1508-1514

90 Piscitelli SC, Burstein AH, Chaitt D, Alfaro RM, Falloon J. Indinavir concentrations and St John's wort. Lancet 2000; 355: 547-548

91 Sugimoto K, Ohmori M, Tsuruoka S, Nishiki K, Kawaguchi A, Harada K, Arakawa M, Sakamoto K, Masada M, Miyamori I, Fujimura A. Different effects of St John's wort on the pharmacokinetics of simvastatin and pravastatin. Clin Pharmacol Ther 2001; 70: 518-524

92 Di YM, Li CG, Xue CC, Zhou SF. Clinical drugs that interact with St. John's wort and implication in drug development. Curr Pharm Des 2008; 14 : 1723-1742

93 Borrelli F, Izzo AA. Herb-drug interactions with St John's wort (Hypericum perforatum): an update on clinical observations. AAPS J 2009; 11: 710-727

94 Zhang L, Zhang Y, Huang SM. Scientific and regulatory perspectives on metabolizing enzyme-transporter interplay and its role in drug interactions: challenges in predicting drug interactions. Mol Pharm 2009; 6: $1766-1774$

95 Patel J, Buddha B, Dey S, Pal D, Mitra AK. In vitro interaction of the HIV protease inhibitor ritonavir with herbal constituents: changes in P-gp and CYP3A4 activity. Am J Ther 2004; 11: 262-277

96 Nabekura T, Kamiyama S, Kitagawa S. Effects of dietary chemopreventive phytochemicals on P-glycoprotein function. Biochem Biophys Res Commun 2005; 327: 866-870

97 Piscitelli SC, Burstein AH, Welden N, Gallicano KD, Falloon J. The effect of garlic supplements on the pharmacokinetics of saquinavir. Clin Infect Dis 2002; 34: 234-238

98 Hajda J, Rentsch KM, Gubler C, Steinert H, Stieger B, Fattinger K. Garlic extract induces intestinal P-glycoprotein, but exhibits no effect on intestinal and hepatic CYP3A4 in humans. Eur J Pharm Sci 2010; 41: 729_ 735

99 Gallicano K, Foster B, Choudhri S. Effect of short-term administration of garlic supplements on single-dose ritonavir pharmacokinetics in healthy volunteers. Br J Clin Pharmacol 2003; 55: 199-202 
100 Berginc K, Trontelj J, Kristl A. The influence of aged garlic extract on the uptake of saquinavir and darunavir into HepG2 cells and rat liver slices. Drug Metab Pharmacokinet 2010; 25: 307-313

101 Berginc K, Milisav I, Kristl A. Garlic flavonoids and organosulfur compounds: impact on the hepatic pharmacokinetics of saquinavir and darunavir. Drug Metab Pharmacokinet 2010; 25: 521-530

102 Dalvi RR. Alterations in hepatic phase I and phase II biotransformation enzymes by garlic oil in rats. Toxicol Lett 1992; 60: 299-305

103 Wu CC, Sheen LY, Chen HW, Kuo WW, Tsai SJ, Lii CK. Differential effects of garlic oil and its three major organosulfur components on the hepatic detoxification system in rats. J Agric Food Chem 2002; 50: 378383

104 Chang TK. Activation of pregnane X receptor (PXR) and constitutive androstane receptor (CAR) by herbal medicines. AAPS J 2009; 11: 590-601

105 Ho BE, Shen DD, McCune JS, Bui T, Risler L, Yang Z, Ho RJ. Effects of garlic on cytochromes P450 2C9- and 3A4-mediated drug metabolism in human hepatocytes. Sci Pharm 2010; 78: 473-481

106 Lawson LD, Wang ZJ, Hughes BG. Identification and HPLC quantitation of the sulfides and dialk(en)yl thiosulfinates in commercial garlic products. Planta Med 1991; 57: 363-370

107 Lawson LD, Gardner CD. Composition, stability, and bioavailability of garlic products used in a clinical trial. J Agric Food Chem 2005; 53: 6254-6261

108 Saw JT, Bahari MB, Ang HH, Lim YH. Potential drug-herb interaction with antiplatelet/anticoagulant drugs. Complement Ther Clin Pract 2006; 12: 236-241

109 Chung KF, Dent G, McCusker M, Guinot P, Page CP, Barnes PJ. Effect of a ginkgolide mixture (BN 52063) in antagonising skin and platelet responses to platelet activating factor in man. Lancet 1987; 1: 248-251

110 [No authors listed]. Haemorrhage due to Ginkgo biloba? Prescrire Int 2008; 17: 19

111 Bone KM. Potential interaction of Ginkgo biloba leaf with antiplatelet or anticoagulant drugs: what is the evidence? Mol Nutr Food Res 2008; 52: 764-771

112 Engelsen J, Nielsen JD, Winther K. Effect of coenzyme Q10 and Ginkgo biloba on warfarin dosage in stable, long-term warfarin treated outpatients. A randomised, double blind, placebo-crossover trial. Thromb Haemost 2002; 87: 1075-1076

113 Gardner CD, Zehnder JL, Rigby AJ, Nicholus JR, Farquhar JW. Effect of Ginkgo biloba (EGb 761) and aspirin on platelet aggregation and platelet function analysis among older adults at risk of cardiovascular disease: a randomized clinical trial. Blood Coagul Fibrinolysis 2007; 18 : 787-793

114 Aruna D, Naidu MU. Pharmacodynamic interaction studies of Ginkgo biloba with cilostazol and clopidogrel in healthy human subjects. $\mathrm{Br}$ J Clin Pharmacol 2007; 63: 333-338

115 Biber A. Pharmacokinetics of Ginkgo biloba extracts. Pharmacopsychiatry 2003; 36 (Suppl. 1): S32-S37

116 Koch $E$. Inhibition of platelet activating factor (PAF)-induced aggregation of human thrombocytes by ginkgolides: considerations on possible bleeding complications after oral intake of Ginkgo biloba extracts. Phytomedicine 2005; 12: 10-16

117 [no authors listed]. Summaries for patients: ginseng reduces the effect of warfarin in a study of healthy volunteers. Ann Intern Med 2004; 141: 158

118 Lee SH, Ahn YM, Ahn SY, Doo HK, Lee BC. Interaction between warfarin and Panax ginseng in ischemic stroke patients. J Altern Complement Med 2008; 14: 715-721

119 Lee YH, Lee BK, Choi YJ, Yoon IK, Chang BC, Gwak HS. Interaction between warfarin and Korean red ginseng in patients with cardiac valve replacement. Int J Cardiol 2010; 145: 275-276

120 Yuan CS, Wei G, Dey L, Karrison T, Nahlik L, Maleckar S, Kasza K, Ang-Lee $M$, Moss J. Brief communication: American ginseng reduces warfarin's effect in healthy patients: a randomized, controlled trial. Ann Intern Med 2004; 141: 23-27

121 Qi LW, Wang CZ, Yuan CS. Ginsenosides from American ginseng: chemical and pharmacological diversity. Phytochemistry 2011; 72: 689-699

122 Legnani C, Frascaro M, Guazzaloca G, Ludovici S, Cesarano G, Coccheri S. Effects of a dried garlic preparation on fibrinolysis and platelet aggregation in healthy subjects. Arzneimittelforschung 1993; 43: 119-122

123 Sunter W. Warfarin and garlic. Pharm J 1991; 246: 722

124 Page RL, Lawrence JD. Potentiation of warfarin by dong quai. Pharmacotherapy 1999; 19: 870-876
125 Lau WC, Welch TD, Shields T, Rubenfire M, Tantry US, Gurbel PA. The effect of St John's Wort on the pharmacodynamic response of clopidogrel in hyporesponsive volunteers and patients: increased platelet inhibition by enhancement of CYP3A4 metabolic activity. J Cardiovasc Pharmacol 2011; 57: 86-93

126 Spigset 0 . Reduced effect of warfarin caused by ubidecarenone. Lancet 1994; 344: 1372-1373

127 Bristol-Myers Squibb Company. COUMADIN (warfarin sodium) tablets. Drug Label. Available at http://www.accessdata.fda.gov/drugsatfda_docs/label/2011/009218s107lbl.pdf. Accessed April 20, 2012

128 Shelton RC. St John's wort (Hypericum perforatum) in major depression. J Clin Psychiatry 2009; 70 (Suppl. 5): 23-27

129 Barbenel DM, Yusufi B, O'Shea D, Bench CJ. Mania in a patient receiving testosterone replacement postorchidectomy taking St John's wort and sertraline. J Psychopharmacol 2000; 14: 84-86

130 Bonetto N, Santelli L, Battistin L, Cagnin A. Serotonin syndrome and rhabdomyolysis induced by concomitant use of triptans, fluoxetine and hypericum. Cephalalgia 2007; 27 : 1421-1423

131 Gordon JB. SSRIs and St. John's Wort: possible toxicity? Am Fam Physician 1998; 57: 950-953

132 Lantz MS, Buchalter E, Giambanco V. St. John's wort and antidepressant drug interactions in the elderly. J Geriatr Psychiatry Neurol 1999; $12: 7-10$

133 Dannawi M. Possible serotonin syndrome after combination of buspirone and St John's Wort. J Psychopharmacol 2002; 16: 401

134 Nathan PJ. Hypericum perforatum (St John's Wort): a non-selective reuptake inhibitor? A review of the recent advances in its pharmacology. J Psychopharmacol 2001; 15: 47-54

135 Schelosky L, Raffauf C, Jendroska K, Poewe W. Kava and dopamine antagonism. J Neurol Neurosurg Psychiatry 1995; 58: 639-640

136 Sarris J, LaPorte E, Schweitzer I. Kava: a comprehensive review of efficacy, safety, and psychopharmacology. Aust NZ J Psychiatry 2011; 45: 27-35

137 Zou L, Henderson GL, Harkey MR, Sakai Y, Li A. Effects of kava (Kavakava, 'Awa, Yaqona, Piper methysticum) on c-DNA-expressed cytochrome P450 enzymes and human cryopreserved hepatocytes. Phytomedicine 2004; 11: 285-294

138 Unger M, Holzgrabe U, Jacobsen W, Cummins C, Benet LZ. Inhibition of cytochrome P450 3A4 by extracts and kavalactones of Piper methysticum (Kava-Kava). Planta Med 2002; 68: 1055-1058

139 Almeida JC, Grimsley EW. Coma from the health food store: interaction between kava and alprazolam. Ann Intern Med 1996; 125: 940-941

140 Teschke R, Schulze J. Risk of kava hepatotoxicity and the FDA consumer advisory. JAMA 2010; 304: 2174-2175

141 Teschke R, Qiu SX, Xuan TD, Lebot V. Kava and kava hepatotoxicity: Requirements for novel experimental, ethnobotanical and clinical studies based on a review of the evidence. Phytother Res 2011; 25: 1263 1274

142 Jones $B D$, Runikis $A M$. Interaction of ginseng with phenelzine. J Clin Psychopharmacol 1987; 7: 201-202

143 Galluzzi S, Zanetti O, Binetti G, Trabucchi M, Frisoni GB. Coma in a patient with Alzheimer's disease taking low dose trazodone and Gingko biloba. J Neurol Neurosurg Psychiatry 2000; 68: 679-680

144 Gharagozloo M, Moayedi B, Zakerinia M, Hamidi M, Karimi M, Maracy $M$, Amirghofran Z. Combined therapy of silymarin and desferrioxamine in patients with beta-thalassemia major: a randomized double-blind clinical trial. Fundam Clin Pharmacol 2009; 23: 359-365

145 Aslam M, Stockley IH. Interaction between curry ingredient (karela) and drug (chlorpropamide). Lancet 1979; 1: 607

146 Heacock PM, Hertzler SR, Williams JA, Wolf BW. Effects of a medical food containing an herbal alpha-glucosidase inhibitor on postprandial glycemia and insulinemia in healthy adults. J Am Diet Assoc 2005; 105: 65-71

147 Panlasigui LN, Panlilio LM, Madrid JC. Glycaemic response in normal subjects to five different legumes commonly used in the Philippines. Int J Food Sci Nutr 1995; 46: 155-160

148 Dresser GK, Spence JD, Bailey DG. Pharmacokinetic-pharmacodynamic consequences and clinical relevance of cytochrome P450 3A4 inhibition. Clin Pharmacokinet 2000; 38: 41-57

149 US Food and Drug Administration. Guidance for industry: Drug interaction studies-study design, data analysis and implications for dosing and labeling. Available at http://www.fda.gov/downloads/Drugs/GuidanceComplianceRegulatoryInformation/Guidances/UCM292362. pdf. Accessed April 1, 2012 
150 Zhao P, Rowland M, Huang SM. Best practice in the use of physiologically-based pharmacokinetic modeling and simulation to address clinical pharmacology regulatory questions. Clin Pharmacol Ther 2012; 92: 17-20

151 Fenneteau F, Poulin P, Nekka F. Physiologically based predictions of the impact of inhibition of intestinal and hepatic metabolism on human pharmacokinetics of CYP3A substrates. J Pharm Sci 2010; 99: 486514

152 Na DH, Ji HY, Park EJ, Kim MS, Liu KH, Lee HS. Evaluation of metabolism-mediated herb-drug interactions. Arch Pharm Res 2011; 34: 1829-1842

153 Gurley BJ, Gardner SF, Hubbard MA, Williams DK, Gentry WB, Carrier J, Khan IA, Edwards DJ, Shah A. In vivo assessment of botanical supplementation on human cytochrome P450 phenotypes: Citrus aurantium, Echinacea purpurea, milk thistle, and saw palmetto. Clin Pharmacol Ther 2004; 76: 428-440

154 Markowitz JS, Devane CL, Chavin KD, Taylor RM, Ruan Y, Donovan JL. Effects of garlic (Allium sativum L.) supplementation on cytochrome P450 2D6 and 3A4 activity in healthy volunteers. Clin Pharmacol Ther 2003; 74: 170-177

155 Liu Z, Li Y, Li X, Ruan CC, Wang LJ, Sun GZ. The effects of dynamic changes of malonyl ginsenosides on evaluation and quality control of Panax ginseng C.A. Meyer. J Pharm Biomed Anal 2012; 64-65: 56-63

156 Muth M, Domanico J, Anderson D, Siegel P, Bloch L. Dietary supplement sales information final report. RTI project number 6673.004. Available at http://vm.cfsan.fda.gov/ acrobat/ds-sales.pdf. Accessed February 10,2012

157 US Food and Drug Administration. Current Good Manufacturing Practice in manufacturing, packaging, labeling, or holding operations for dietary supplements. Available at http://gpo.gov/fdsys/pkg/FR-200706-25/html/07-3039.htm. Accessed June 10, 2012

158 US Food and Drug Administration. Federal Register Interim Final Rule - 72 FR 34959: Petition to request an exemption from 100 percent identity testing of dietary ingredients: Current good manufacturing practice in manufacturing, packaging, labeling, or holding operations for dietary supplements. Available at http://www.fda.gov/Food/DietarySupplements/GuidanceComplianceRegulatoryInformation/RegulationsLaws/ucm079573.htm. Accessed June 10, 2012

159 Godtel-Armbrust U, Metzger A, Kroll U, Kelber O, Wojnowski L. Variability in PXR-mediated induction of CYP3A4 by commercial preparations and dry extracts of St. John's wort. Naunyn Schmiedebergs Arch Pharmacol 2007; 375: 377-382

160 Mai I, Bauer S, Perloff ES, Johne A, Uehleke B, Frank B, Budde K, Roots I. Hyperforin content determines the magnitude of the St John's wortcyclosporine drug interaction. Clin Pharmacol Ther 2004; 76: 330340

161 Mueller SC, Majcher-Peszynska J, Uehleke B, Klammt S, Mundkowski RG, Miekisch W, Sievers H, Bauer S, Frank B, Kundt G, Drewelow B. The extent of induction of CYP3A by St. John's wort varies among products and is linked to hyperforin dose. Eur J Clin Pharmacol 2006; 62: 29-36

162 Mueller SC, Majcher-Peszynska J, Mundkowski RG, Uehleke B, Klammt S, Sievers H, Lehnfeld R, Frank B, Thurow K, Kundt G, Drewelow B. No clinically relevant CYP3A induction after St. John's wort with low hyperforin content in healthy volunteers. Eur J Clin Pharmacol 2009; 65: 81-87

163 Vlachojannis J, Cameron M, Chrubasik S. Drug interactions with St. John's wort products. Pharmacol Res 2011; 63: 254-256

164 Huang SM, Hall SD, Watkins P, Love LA, Serabjit-Singh C, Betz JM, Hoffman FA, Honig P, Coates PM, Bull J, Chen ST, Kearns GL, Murray MD. Drug interactions with herbal products and grapefruit juice: a conference report. Clin Pharmacol Ther 2004; 75: 1-12

165 Venkataramanan R, Ramachandran V, Komoroski BJ, Zhang S, Schiff PL, Strom SC. Milk thistle, a herbal supplement, decreases the activity of CYP3A4 and uridine diphosphoglucuronosyl transferase in human hepatocyte cultures. Drug Metab Dispos 2000; 28: 1270-1273

166 Zuber R, Modriansky M, Dvorak Z, Rohovsky P, Ulrichova J, Simanek V, Anzenbacher $P$. Effect of silybin and its congeners on human liver microsomal cytochrome P450 activities. Phytother Res 2002; 16: 632638

167 Brantley SJ, Oberlies NH, Kroll DJ, Paine MF. Two flavonolignans from milk thistle (Silybum marianum) inhibit CYP2C9-mediated warfarin metabolism at clinically achievable concentrations. J Pharmacol Exp Ther 2010; 332: 1081-1087
168 Fuhr U, Beckmann-Knopp S, Jetter A, Luck H, Mengs U. The effect of silymarin on oral nifedipine pharmacokinetics. Planta Med 2007; 73: 1429-1435

169 Han Y, Guo D, Chen Y, Chen Y, Tan ZR, Zhou HH. Effect of silymarin on the pharmacokinetics of losartan and its active metabolite E-3174 in healthy Chinese volunteers. Eur J Clin Pharmacol 2009; 65: 585-591

170 Zhang S, Morris ME. Effects of the flavonoids biochanin A, morin, phloretin, and silymarin on P-glycoprotein-mediated transport. J Pharmacol Exp Ther 2003; 304: 1258-1267

171 Zhang S, Yang X, Morris ME. Flavonoids are inhibitors of breast cancer resistance protein (ABCG2)-mediated transport. Mol Pharmacol 2004; 65: $1208-1216$

172 Deng JW, Shon JH, Shin HJ, Park SJ, Yeo CW, Zhou HH, Song IS, Shin JG. Effect of silymarin supplement on the pharmacokinetics of rosuvastatin. Pharm Res 2008; 25: 1807-1814

173 Gurley BJ, Barone GW, Williams DK, Carrier J, Breen P, Yates CR, Song PF, Hubbard MA, Tong Y, Cheboyina S. Effect of milk thistle (Silybum marianum) and black cohosh (Cimicifuga racemosa) supplementation on digoxin pharmacokinetics in humans. Drug Metab Dispos 2006; 34: 69-74

174 DiCenzo R, Shelton M, Jordan K, Koval C, Forrest A, Reichman R, Morse G. Coadministration of milk thistle and indinavir in healthy subjects. Pharmacotherapy 2003; 23: 866-870

175 Piscitelli SC, Formentini E, Burstein AH, Alfaro R, Jagannatha S, Falloon J. Effect of milk thistle on the pharmacokinetics of indinavir in healthy volunteers. Pharmacotherapy 2002; 22: 551-556

176 Mills E, Wilson K, Clarke M, Foster B, Walker S, Rachlis B, DeGroot N, Montori VM, Gold W, Phillips E, Myers S, Gallicano K. Milk thistle and indinavir: a randomized controlled pharmacokinetics study and meta-analysis. Eur J Clin Pharmacol 2005; 61: 1-7

177 Rao BN, Srinivas M, Kumar YS, Rao YM. Effect of silymarin on the oral bioavailability of ranitidine in healthy human volunteers. Drug Metabol Drug Interact 2007; 22: 175-185

178 Rajnarayana K, Reddy MS, Vidyasagar J, Krishna DR. Study on the influence of silymarin pretreatment on metabolism and disposition of metronidazole. Arzneimittelforschung 2004; 54: 109-113

179 Abenavoli L, Capasso R, Milic N, Capasso F. Milk thistle in liver diseases: past, present, future. Phytother Res 2010; 24: 1423-1432

180 Kroll DJ, Shaw HS, Oberlies NH. Milk thistle nomenclature: why it matters in cancer research and pharmacokinetic studies. Integr Cancer Ther 2007; 6: 110-119

181 Schrieber SJ, Wen Z, Vourvahis M, Smith PC, Fried MW, Kashuba AD, Hawke RL. The pharmacokinetics of silymarin is altered in patients with hepatitis $C$ virus and nonalcoholic fatty liver disease and correlates with plasma caspase-3/7 activity. Drug Metab Dispos 2008; 36: 1909-1916

182 Gorski JC, Huang SM, Pinto A, Hamman MA, Hilligoss JK, Zaheer NA, Desai $M$, Miller M, Hall SD. The effect of echinacea (Echinacea purpurea root) on cytochrome P450 activity in vivo. Clin Pharmacol Ther 2004; 75: 89-100

183 Xie HG, Kim RB. St John's wort-associated drug interactions: shortterm inhibition and long-term induction? Clin Pharmacol Ther 2005; 78: 19-24

184 Markowitz JS, Devane CL, Boulton DW, Carson SW, Nahas Z, Risch SC. Effect of St. John's wort (Hypericum perforatum) on cytochrome P-450 2D6 and 3A4 activity in healthy volunteers. Life Sci 2000; 66: L133-L139

185 Imai H, Kotegawa T, Tsutsumi K, Morimoto T, Eshima N, Nakano S, Ohashi $K$. The recovery time-course of CYP3A after induction by St John's wort administration. Br J Clin Pharmacol 2008; 65: 701-707

186 Dresser GK, Schwarz UI, Wilkinson GR, Kim RB. Coordinate induction of both cytochrome P4503A and MDR1 by St John's wort in healthy subjects. Clin Pharmacol Ther 2003; 73: 41-50

$187 \mathrm{Hu}$ M, Wang DQ Xiao YJ, Mak VW, Tomlinson B. Herb-drug interactions: methods to identify potential influence of genetic variations in genes encoding drug metabolizing enzymes and drug transporters. Curr Pharm Biotechnol 2012; 13: 1718-1730

188 Yin OQ Tomlinson B, Waye MM, Chow AH, Chow MS. Pharmacogenetics and herb-drug interactions: experience with Ginkgo biloba and omeprazole. Pharmacogenetics 2004; 14: 841-850

189 Dietary Supplement Health and Education Act of 1994 (DSHEA). Available at http://www.fda.gov/RegulatoryInformation/Legislation/ FederalFoodDrugandCosmeticActFDCAct/SignificantAmendmentstotheFDCAct/ucm148003.htm. Accessed January 29, 2012 
190 Dietary Supplement and Nonprescription Drug Consumer Protection Act. Available at http://www.gpo.gov/fdsys/pkg/PLAW-109publ462/ pdf/PLAW-109publ462.pdf. Accessed June 10, 2012

191 US Food and Drug Administration. Requirements on the content and format of labeling for human prescription drug and biological products. Available at http://www.fda.gov/Drugs/GuidanceComplianceRegulatoryInformation/LawsActsandRules/ucm084159.htm. Accessed June 12, 2012

192 US Food and Drug Administration, Center for Drug Evaluation and Research. Guidance for industry-Botanical drug products. Available at http://www.fda.gov/dowloads/Drugs/GuidanceComplianceRegulatoryInformation/Guidances/ucm070491.pdf. Accessed February 10, 2012

193 Wu KM, Dou J, Ghantous H, Chen S, Bigger A, Birnkrant D. Current regulatory perspectives on genotoxicity testing for botanical drug product development in the U.S.A. Regul Toxicol Pharmacol 2010; 56: 1-3

194 De Castro WV, Mertens-Talcott S, Rubner A, Butterweck V, Derendorf H. Variation of flavonoids and furanocoumarins in grapefruit juices: a potential source of variability in grapefruit juice-drug interaction studies. J Agric Food Chem 2006; 54: 249-255

195 Woelkart K, Feizlmayr E, Dittrich P, Beubler E, Pinl F, Suter A, Bauer R Pharmacokinetics of bilobalide, ginkgolide $A$ and $B$ after administration of three different Ginkgo biloba L. preparations in humans. Phytother Res 2010; 24: 445-450
196 Ding S, Dudley E, Plummer S, Tang J, Newton RP, Brenton AG. Quantitative determination of major active components in Ginkgo biloba dietary supplements by liquid chromatography/mass spectrometry. Rapid Commun Mass Spectrom 2006; 20: 2753-2760

197 Kim KA, Park PW, Park JY. Short-term effect of quercetin on the pharmacokinetics of fexofenadine, a substrate of P-glycoprotein, in healthy volunteers. Eur J Clin Pharmacol 2009; 65: 609-614

198 Han Y, Guo D, Chen Y, Tan ZR, Zhou HH. Effect of continuous silymarin administration on oral talinolol pharmacokinetics in healthy volunteers. Xenobiotica 2009; 39: 694-699

199 Penzak SR, Robertson SM, Hunt JD, Chairez C, Malati CY, Alfaro RM, Stevenson JM, Kovacs JA. Echinacea purpurea significantly induces cytochrome P450 3A activity but does not alter lopinavir-ritonavir exposure in healthy subjects. Pharmacotherapy 2010; 30: 797-805

200 Lilja JJ, Kivisto KT, Neuvonen PJ. Grapefruit juice-simvastatin interaction: effect on serum concentrations of simvastatin, simvastatin acid and HMG-CoA reductase inhibitors. Clin Pharmacol Ther 1998; 64: 477-483

201 Merck \& Co. ZOCOR (simvastatin) Tablets. Drug label. Available at http://www.accessdata.fda.gov/drugsatfda_docs/label/2012/ 019766s085lbl.pdf. Accessed April 1, 2012

202 Tapaninen T, Neuvonen PJ, Niemi M. Grapefruit juice greatly reduces the plasma concentrations of the OATP2B1 and CYP3A4 substrate aliskiren. Clin Pharmacol Ther 2010; 88: 339-342 